\title{
$\pm .3744$
}

\section{COMPOSITE QUARTERLY TECHNICAL REPORT LONG-TERM HIGH-LEVEL-WASTE TECHNOLOGY}

OCTOBER - DECEMBER 1981

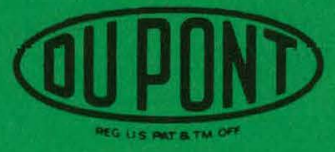

E. I. du Pont de Nemours \& Co. Savannah River Laboratory

Aiken, SC 29808 


\section{DISCLAIMER}

This report was prepared as an account of work sponsored by an agency of the United States Government. Neither the United States Government nor any agency Thereof, nor any of their employees, makes any warranty, express or implied, or assumes any legal liability or responsibility for the accuracy, completeness, or usefulness of any information, apparatus, product, or process disclosed, or represents that its use would not infringe privately owned rights. Reference herein to any specific commercial product, process, or service by trade name, trademark, manufacturer, or otherwise does not necessarily constitute or imply its endorsement, recommendation, or favoring by the United States Government or any agency thereof. The views and opinions of authors expressed herein do not necessarily state or reflect those of the United States Government or any agency thereof. 


\section{DISCLAIMER}

Portions of this document may be illegible in electronic image products. Images are produced from the best available original document. 



\section{COMPOSITE QUARTERLY TECHNICAL REPORT LONG-TERM HIGH-LEVEL-WASTE TECHNOLOGY}

\section{OCTOBER - DECEMBER 1981}

$$
\text { DP }--81-157-4
$$

DE82 016240

W. R. Cornman, Compiler

Approved by:

D. E. Gordon, Planning Coordinator Waste Management Planning Division

Publication Date: June 1982

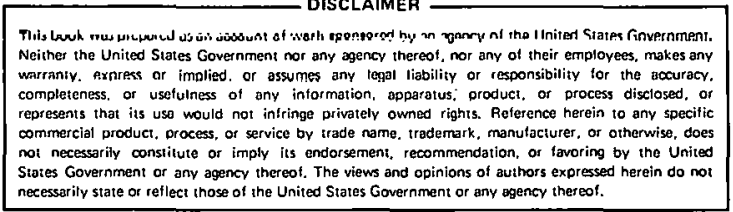

Issued by E. I. du Pont de Nemours \& Co. Savannah River Laboratory Aiken, SC 29808

PREPARED FOR THE U. S. DEPARTMENT OF ENERGY UNDER CONTRACT DE-ACO9-76SR00001 
THIS PAGE

\section{WAS INTENTIONALLY \\ LEFT BLANK}

$-2-$ 
This composite quarterly technical report summarizes work performed at participating sites to immobilize high-level radioactive wastes. This work is under the direction of the Savannah River Operations Office of the Department of Energy (DOE-SR). The Savannah River Laboratory, operated by E. I. du Pont de Nemours \& Co. for the U.S. Department of Energy, is serving as the lead office for this program to provide technical assistance to DOE-SR and to coordinate the work at the participating sites.

This series of reports summarizes research and development studies on the immobilization of high-level wastes from the chemical reprocessing of nuclear reactor fuels. Immobilization of the wastes (defense and commercial) consists of placing them in a high-integrity form with a very low potential for radionuclide release. Immobilization of commercial wastes is being considered on a contingency basis in the event that reprocessing is resumed.

The basic plan for meeting the goal of immobilization of the DOE high-level wastes is 1) to develop technology to support a realistic choice of waste form alternatives for each of the three (SRP, ICPP, and RHO) DOE sites, 2) to develop product and processing technology with sufficient scaleup to provide design data for full-scale facilities, and 3 ) to support R\&D for construction and operation of immobilization facilities.

Participants in the high-level waste management program are:

Argonne Nationa 1 Laboratory (ANL)

Satholic University of America (CUA)

Goddard Space Flight Center (NASA)

Idaho Chemical Processing Plant (ICPP)

Lawrence Livermore National Laboratory (LLNL)

Materials Characterization Center-PNL (MCC)

Materials Review Board-ANL (MRB)

North Carolina State University (NCSU)

Oak Ridge National Laboratory (ORNL)

Pacific Northwest Laboratory (PNL)

Rockwell Energy Systems Group (RES)

Rockwell Hanford Operation (RHO)

Sandia National Laboratories (SAND)

Savannah River Laboratory (SRL)

University of Florida (UFLA)

University of South Carolina (USC)

Westinghouse Research and Development Center (WEST) 
Most of the existing high-level nuclear wastes in the United States have been generated in defense activities of DOE at the Savannah River Plant (SRP), Aiken, SC; at Hanford, WA; and at the Idaho Chemical Processing Plant. An inventory of approximately 70 million gallons of high-level defense waste is on hand with a continuous annual production rate of 0.5 to 1.0 million gallons.

This series of quarterly technical reports is supplemented with a series of monthly manement summary reports. 
INTRODUCTION 7

SUMMARY 9

PROGRAM STATUS 11

Waste Preparation (1.2) 11

$$
\begin{array}{ll}
\text { In-Situ Storage or Disposal (1.2.1) } & 11 \\
\text { Residual Liquid Solidification - RHO } & 11 \\
\text { In-Situ Drying - RHO } 13 & \\
\hline \text { Capsule Corrosion Studies - RHO } 15
\end{array}
$$

Waste Fixation (1.3) 17

Waste Form Development and Characterization (1.3.1) 17

General 17

Alternative Waste Form Development - PNL 17

Alternative Waste Form Development - SRL 18

Sol-Gel Technology - ORNL 33

Neutron Activation and Tracer Studies - ANL 34

Brittle Fracture Studies - ANL 38

Activities of the Materials Characterization Center - MCC 47

Fixation of Waste in Glass 49

The Porous Glass Matrix Process for Fixation of Nuclear Wastes - COA 49

Durability of SRP. Waste Glass - Effects of Waste Loading - SRL 57

Fixation of Waste in Concrete 57

Characterization of FUETAP Concrete - ORNL 57 
Fixation of Waste in Tailored Ceramics 58

Ceramic Formulations for SRP High-Level Wastes - RES 58

Development of Crystalline Ceramic Waste Forms-

Final Report - ANL 65

Coated Waste Forms 65

Sol-Gel Coated Particles - ORNL 65

Process and Equipment Development (1.3.2) 66

SYNROC D Reference Process - LLNL 66

Radioactive Demonstration of Westinghouse

Ge1-Glass Process - PNL 75

Large-Scale Glass Melter Development Program - SRL 75

Ful1-Scale Slurry-Fed In-Can Melter - SRL 76

Inconel 690 Wear Tests in the Small Cylindrical Melter - SRL 77

Final Handling $(1 . .4) \quad 78$

Canister Development and Characterization (1.4.1) 78

High-Level Waste Canister Development - PNL 78

Helium Verification for: DWPF Canister

Leak Tests - SRL 79

REFERENCES $\quad 80$ 
The technical information included in this report is structured along the lines of the Work Breakdown Structure (WBS) adopted for use in the High-Level. Waste Technology Program. A description of the functions and work elements of the WBS are as follows:

FUNCTION AND WORK ELEMENTS FOR THE HIGH-LEVEL WASTE LONG-TERM MANAGEMENT PROGRAM

Function 1.1 - Program Management and Support

Work Element 1.1.1 - Management and Budget

Includes development of program plans and budget documents, program administration and reporting, and independent program evaluations.

Work Element 1.1.2 - Environmental and Safety Assessments

Includes studies related to preparation of NEPA documentation.

Work Element 1.1.3 - Other Support

Includes technical data, cost-benefit assessments, and other analyses in support of conceptual design and engineering studies leading up to an approved 1 ine item project, but does not include capital line item design or engineering studies.

\section{Function 1.2 - Waste Preparation}

Work Element 1.2.1 - In-Situ Storage or Disposa 1

Limited to those activities related to retention of waste in its existing containment, with any appropriate modifications to either the waste or the containment as an alternative to Waste Retrieval. 
Work Element 1.2.2 - Waste Retrieval

From existing containment.

Work Element 1.2.3 - Separation and Concentration

Includes bulk decontamination and preparation of suitable feed for fixation.

Function 1.3 - Waste Fixation

Work Element 1.3.1 - Waste Form Development and Characterization

Basic studies on waste forms and their performance.

Work Element 1.3.2 - Process and Equipment Development

Work directed toward evolution of a practical process for producing waste forms.

Function 1.4 - Fina 1 Hand ling

Work Element 1.4.1 - Canister Development and Characterization

. Includes activities related to canister material evaluation, waste form compatibility with canister materials, decontamination, canister sealing, heat transfer studies, and quality control of the final immobilization product (waste form in canister).

Work Element 1.4.2 - Onsite Storage or Disposal

Includes provision for either interim or long-term storage of waste packages, as an alternative to offsite transporation. 
Waste Preparation (1.2)

Solidification of in-tank liquids is being studied at RHO.

Demonstration of in-tank drying and consolidation of wet synthetic salt is underway at RHO.

Studies are underway at RHO to obtain data needed to design insulated containers for ${ }^{137} \mathrm{CsCl}$ capsules. Page 15

Waste Fixation (1.3)

PNL multibarrier waste form activities are summarized.

Complete results of the SRL Comparative Leach Test Program are available for seven elements leached from forms with three different simulated waste sludges.

A conceptual design of a ceramic form and canister was deve1oped at SRL for possible use in the DWPF.

Batches of gel spheres containing simulated commercial power reactor waste were produced at ORNL.

Studies continued at ANL to qualify the use of neutron activation analysis (NAA) and radioactive tracers for measuring leach rates from defense and commercial waste glasses.

Page 34

Experimental results were used at ANL to establish preliminary correlations of lognormal size-distribution parameters, fracture surface areas, and material strength properties of brittle waste forms of various sizes and configurations. Page 38 by MCC.

Two documents containing standard test methods were published

Optimized parameters for the porous-glass matrix (PGM) process and leach test data on optimized PGM waste forms are reported by Catholic University. 
The leachability of borosilicate glass as a function of waste loading is reported by SRL.

Ceramic formulations for immobilizing SRP High-Level Waste are described by RES. Page 58

Leach tests were conducted on coated and uncoated particles at ORNL.

A reference process for the preparation of SYNROC D is described by LLNL.

Page 66

A radioactive demonstration of the Westinghouse gel-glass process was completed at PNL.

Development continued at SRL on the Large-Scale Slurry-Fed Glass Melter and the Ful1-Scale Slurry-Fed In-Can Melter.

Page 75

\section{Final Handling (1.4)} at PNL.

Experimental work on barrier canister materials was completed Page 78 


\section{Waste Preparation ( 1.2$)$}

\section{In-Situ Storage or Disposal $(1.2 .1)$}

Residual Liquid Solidification - RHO. The objective of this task is to determine a suitable method, technical feasibility, and economic advantages of solidifying Hanford Defense Residual Liquor (HDRL), future customer liquid wastes, double-shell slurry, sludge washing solutions, and potential Purex decladding wastes in a manner suitable for near-surface in-tank in situ disposal in accordance with proposed criteria and standards.

Potentially, all Hanford terminal liquids that are low in complexant content and low in transuranic content might qualify for solidification and near-surface or in-tank disposal. To date, all analyses of filtered low complexant alkaline residual liquids have indicated TRU contents of less than $10 \mathrm{nCi} / \mathrm{gm}$.

Thermal analyses of tank waste and structural components using the HEATING-5 codel have shown that the heat content of solidified, dried waste in-tank in the disposal mode with barriers in place shall be 1 imited to about $30,000 \mathrm{BTU} / \mathrm{hr}$. The actual amount of radiolytic heat that can be disposed of in-tank while maintaining structural integrity is dependent upon the size of tank, the waste depth, the dome-fill material, selection of single- or double-shell tanks, tank location in the tank farm, the moisture content of the soil, and the degree of dryness of the waste at time of entombment or isolation.

Four primary methods of liquid solidification (see Table 1) are being considered:

\section{TABLE 1}

\section{Liquid Solidification Methods}

In situ radiolytic heating of non-pumpable "hot" tanks.

Microwave heating of non-pumpable "cold" tanks.

Dver-the-tank wiped-film-evaporator solidification of pumpable liquids.

Vacuum-evaporator-crystallizer slurry concentration followed by final drying by one of the above methods. 
-Preliminary progress to date indicates that salt-well pumped 1 iquids can be solidified to about 10 to 15 percent residua 1 moisture content (based upon Wiped Film Evaporator (WFE) pilot plant tests on synthetic HDRL) with a 48 to 65 percent waste volume reduction factor.

The WFE product flows at $150^{\circ} \mathrm{C}$ from the open end of the WFE mounted in a 42-inch tank riser. The product spreads into and across the salt cake existing in the tank as the product cools and solidifies.

A preconceptual design of a portable Wiped Film Evaporator system capable of being moved from tank to tank was completed. ${ }^{2}$ This system was based upon using the two existing and available Wiped Film Evaporators developed and built for Savannah River Laboratory. This system was also designed to be self-contained, requiring only additional electric power to be brought to the tank farms. It was scoped to utilize existing salt-well pumping facilities and pump pits over existing 42-inch risers.

Based upon TRAC-1 inventury data, the proposed criteria and standards, and the thermal limitations discussed in this report, ample space has been identified to receive all of the solidified salt-well pumped 1 iquids into non-transuranic single-shell tanks that are already equipped with pump pits on $42-$ inch risers.

Work is continuing to determine performance, installation, process control, effluent control, safety, and cost requirements of the system. Technical and economic comparisons to cross site transfer, vacuum-eva porator crystallization, subsequent storage and solidification, and disposal into newly constructed doubleshell tanks are being developed.

Samples of Hanford simulated salt-well liquor from the Wiped Film Evaporator test runs completed by Associated Technology Incorporated (ATI) using LUWA Corporation's pilot plant facilities in Charlotte, North Carolina were examined. The 150 psig steam runs were selected for testing. Over a wide range of feed rates, product moisture varied from about $30 \%$ to $5 \%$; product softening point varied from $24^{\circ} \mathrm{C}$ to $63^{\circ} \mathrm{C}$; and product pour point varied from $24^{\circ} \mathrm{C}$ to $130^{\circ} \mathrm{C}$, respectively. Wiped Film Evaporator performance analysis is being centered on the $10 \% \pm 5$ percent product moisture operating conditions.

Individual and overall single shell tank (SST) capacities, identification of specific receiver tanks, and time required for salt-well liquor (SWL) processing were identified. Cost analysis of the Wiped Film Evaporator system is proceeding. 
In-Situ Drying - RHO. The objective of this task this year is to demonstrate in-tank drying and consolidation of wet synthetic salt in a 1/12-scale tank with a microwave drying system.

Several advanced stabilization concepts have been studied in prior years at Hanford. The two most promising and recommended methods were buried wave guide heating and A.C. electric resistance heating. All of these conceptual systems had serious limitations and did not offer sufficient promise to be developed at that time.

Most recently the laboratory has conducted a feasibility experiment based upon uniformly heating the damp in-tank wastes by means of microwaves uniformly dispersed over the waste surface from wave guides passed through risers into the tank dome void volume.

Conceptually, the system would use approximately four to six coaxial wave guides inserted through four to six 6 -inch or 12-inch risers located on about a 20-foot radius from the tank center. The wave guides would require a microwave generator capacity totalling 300 to $400 \mathrm{~kW}$.

The expected generator frequency would be nearly 200 megahertz for the 75-foot-diameter tanks filled within twelve to fifteen feet from the dome center, i.e. capacity. The top of the damp wastes would be covered by a few inches of porous insulation such as vermiculite or clay. The five-foot wavelength radiation would pass through the insulation with low albedo and be mostly absorbed in the first few inches of damp wastes. At the beginning of operation, about $50 \%$ of the radiation might be reflected to the tank dome where a portion is absorbed and the majority is reflected by the rebar steel back to the waste surface. ThousandCFM HEPA filtered portable exhausters will pull dry air into the tank void to cool the dome and carry out moisture to an external condenser.

As drying progresses, the waste surface albedo will decrease to less than $25 \%$, and the microwaves will penetrate deeper into the waste to react with dampness. At 150 to 200 megahertz, the radiation will progressively penetrate to the tank bottom to heat and vaporize the residual liquid heel that remains after jet pumping. A typical tank containing about 600,000 gallons of damp waste with a 30,000 -gallon liquid heel is expected to require about three months to heat up and dry out the contents to about four to six percent moisture.

A small one-twelfth scale experiment was set up utilizing an insulated six-foot-diameter steel tank thirty-inches high with a four-inch concrete dome and a less-than-one-inch wire mesh. A 
2,450 megahertz 12-kilowatt generator that produced about fiveinch wavelength radiation was used. The tank was filled with 8$1 / 2$ inches of simulated salt cake mush containing $30 \%$ moisture covered with two to four inches of vermiculite insulation.

Four small 1 1/2- by 3-inch guides were introduced into holes in the dome. The initial air sweep was $300 \mathrm{CFM}$. The unit was operated at low power for about ten hours until the wet salt surface attained nearly $100^{\circ} \mathrm{C}$. Power was increased slowly to $8 \mathrm{~kW}$ over another 12 hours until the bottom of the tank attained $95^{\circ} \mathrm{C}$.

Power was then decreased to $5 \mathrm{~kW}$ and held for an additional fifty hours until the top of the salt cake attained $350^{\circ} \mathrm{C}$, the bottom was $150^{\circ} \mathrm{C}$, and moisture no longer collected in the outlet air stream condenser. During the entire experiment, the concrete dome was held to about $80^{\circ} \mathrm{C}$. When the salt cake returned to room temperature, it had decreased in volume to seven inches of depth and was a very dry, hard, strong, dense cake. Samples chipped out demonstrated dry granular properties and were analyzed to contain four percent residual moisture. Metal tubing and thermocouple wires showed no evidence of being affected by the microwaves. A detailed report is in preparation.

Conceptual analysis indicates that a 600,000-gallon salt cake with a residual heel of 33,000 gallons of liquid can be brought to temperature in 20 to 40 days with $300 \mathrm{~kW}$ of 200 megahertz input. Studies indicate drying will require an additional 15 to 20 days. At that time, salt temperatures will be $160^{\circ} \mathrm{C}$ to $170^{\circ} \mathrm{C}$, moisture less than four percent, and tank dome temperature less than $100^{\circ} \mathrm{C}$.

Waste Tank Corrosion Studies - RHO. Corrosion tests began which will determine the effects of several waste streams expected from the Purex facility after startup. Testing is divided into short-term (four months) and long-term (twelve months). These tests will conclude in April and December of 1982, respectively. Customer waste tests are being prepared for startup. This included establishing detailed composition specifications, preparing test solutions, putting together each of the test assemblies, labeling and recording the assemblies in log books, and emplacing into the water baths.

There are no observed differences in corroded surfaces of the two carbon steel alloys being tested. The alloys being tested are those used in single-shell tanks (Type I) and in double-shell tanks (Type II). Scanning electron microscope (SEM) examinations were performed on coupons recently tested in double-shell slurry (DSS) solutions. There are observable differences which are caused by composition and temperature variations within each alloy series. These differences are not a cause for concern. 
Capsule Corrosion Studies - RHO. The compatibility testing program calls for the ${ }^{137} \mathrm{CsCl}$ capsules to be placed in insulated containers and allowed to self-heat to a nominal chloride/metal interface temperature of $450^{\circ} \mathrm{C}$. Heat transfer studies were carried out using an electriçally heated dummy capsule to obtain the data needed to design the insulated container.

The design of the containers is complicated by the fact that there is some discrepancy in the available data on how much gamma energy is absorbed in the Waste Encapsulation and Storage Facility (WESF) capsule (essentially all of the beta energy is absorbed in the capsule). An additional complication in design of the container is that the curie content of the capsules varies widely from batch to batch.

Four sections of $304 \mathrm{~L}$ stainless steel tubing were welded longitudinally to the outer capsule surface at $0^{\circ}, 90^{\circ}, 120^{\circ}$, and $270^{\circ}$ to serve as thermowells. Four movable thermocouples inserted in the thermowells served to measure the capsule temperature at various locations along its lengths. Outputs of the thermocouples were monitored with a digital thermometer. The thermocouples and digital thermometer were calibrated prior to use.

Preliminary heating tests showed that an inner capsule temperature of $450^{\circ} \mathrm{C}$ can be achieved with one inch of insulation around the capsule and a power input to the heater of 157 watts. Assuming that $50 \%$ of the energy from a WESF $137 \mathrm{CsCl}$ capsule is absorbed in the capsule, the capsule would have to have a total energy of about 250 watts to give a $450^{\circ} \mathrm{C}$ inner capsule temperature with one inch of insulation. This power level has been achieved in WESF in the past and should be achievable in the future.

The preliminary heating tests also pointed out other factors that must be considered.

A substantial temperature gradient exists along the length of the inner and outer capsules with the maximum temperatures occurring nine to twelve inches up from the bottom of the outer capsule. Depending on the power input (132-175 watts), the temperature gradients between the ends of the capsules and the point of maximum temperature varied from $80^{\circ} \mathrm{C}$ to $150^{\circ} \mathrm{C}$.

- The temperature difference between the inner and outer capsules varied between $12^{\circ} \mathrm{C}$ and $44^{\circ} \mathrm{C}$ over the length of the capsules. Power input has surprisingly little effect on the temperature difference between the capsules over the range studied (132-175 watts). For example, at a power input of 132 watts, the maximum temperature difference between the inner and outer capsules - was $40^{\circ} \mathrm{C}$. 
- The temperature of the outer capsule was measured at four different radial locations. At a given elevation, the temperatures at the four locations never varied by more than $3-5^{\circ} \mathrm{C}$. Even when the inner capsule was positioned so that it touched the side of the outer capsule, the temperature variation around the outer capsule at a given elevation was never more than $5^{\circ} \mathrm{C}$.

Tests with the electrically heated dummy capsule are continuing in order to refine the design of the insulated container. The tests will be completed in January 1982. All indications are that an insulated container using 1 to $1-1 / 2$ inches of insulation will provide the necessary self-heating to give a maximum $\mathrm{CsCl} / m e t a l$ interface temperature of $450^{\circ} \mathrm{C}$.

Work on a thermodynamic analysis of the compatibility of WESF $137 \mathrm{CsCl}$ with $316 \mathrm{~L}$ stainless steel was started. Published free energy of formation data for the metal chlorides has been assembled. Efforts are now underway to calculate free energies of mixing for the components of $316 \mathrm{~L}$ stainless steel in the solutionannealed form. Preliminary calculations indicate that potentially serious reactions could occur between impurity chlorides in the $\mathrm{CsCl}$ and any chromium carbide precipitates in the stainless steel .which may form during capsule storage at elevated temperatures.

Preliminary differential scanning colorimetry studies and thermal expansion measurements were performed on $\mathrm{CsCl}$ containing substantial amounts of $\mathrm{NaCl}$ and $\mathrm{KCl}$ (5-10 wt \% $\mathrm{NaCl}+\mathrm{KCl}$ ).. The studies show that melting of the CsCl-KCl-NaCl eutectic occurs at $475-480^{\circ} \mathrm{C}$, and transformation to the high temperature solid phase starts at $320-330^{\circ} \mathrm{C}$. When the three-component system is then cooled, there is only partial reversion to the low-temperature crystalline phase. These results confirm those obtained in earlier studies and show that in a geologic repository where the $\mathrm{CsC1/316L}$ stainless interface temperature is $450^{\circ} \mathrm{C}$, some liquid chloride phase would be present; and the solid material would be in the high temperature form.

As part of the CsCl compatibility program, it is highly desirable to have reliable data on the impurities present in the WESF ${ }^{137} \mathrm{CsCl}$. Adequate procedures are not currently available for analyzing low levels of impurities in the CsCl because of the large dilutions required prior to analys is of the ${ }^{137} \mathrm{CsCl}$. A procedure was examined for stripping the cesium from the dissolved ${ }^{137} \mathrm{CsCl}$ by zeolite ion exchange and leaving the impurities in the aqueous solution. The solution from which the $137 \mathrm{Cs}$ was stripped could then be analyzed for impurities by standard techniques (i.e., AA, ICP). Unfortunately, the results obtained showed that the $137 \mathrm{Cs}$ was not adequately removed by the exchanger to allow subsequent analysis of the aqueous solution. Modifications of the procedure are now being studied to see if the ${ }^{137} \mathrm{Cs}$ removal can be improved sufficiently to permit analysis of the aqueous solution.

$$
-16 \text { - }
$$


Waste Fixation (1.3)

Waste Form Development and Characterization (1.3.1)

\section{Genera 1}

Alternative Waste Form Development - PNL. Four topical reports summarizing past multibarrier waste form activities have been completed. The reports are:

- J.W. Wald, et al. Development and Testing of Matrices for Encapsulation of Glass and Ceramic Nuclear Waste Forms. PNL-4098.

- K. H. Oma, et al. Coated Particle Waste Form Development. PNL-4108.

- R. L. Treat, and J. M. Rusin. Consolidated Waste Form Development. PNL-4146.

- W. J. Gray, J. W. Wald, and R. P. Turcotte. Radiation Damage Studies Related to Nuclear Waste Forms. PNL-4145.

Three of the reports, PNL-4098, PNL-4108, and PNL-4146, describe the development and fabrication of ceramic pellets and glass marbles that were subsequently coated or encapsulated to produce multibarrier waste forms. The fourth report, PNL-4145, discusses the effects of cesium transmutation on the properties of high-level waste solids and the alpha radiation effects of two specific crystalline materials: $\mathrm{Gd}_{2} \mathrm{Ti}_{2} \mathrm{O}_{7}$ and $\mathrm{CaZrTi}_{2} \mathrm{O}_{7}$.

The multibarrier concept utilizes an inner core material which may be based upon either a ceramic or glass waste form. The option exists to coat the particles to provide additional leach resistance. To complete the multibarrier concept, coated or uncoated particles are encapsulaled in matrix matcrialo that include metal alloys, glass frits, graphite, and hot-pressed or castable ceramics. Major conclusions based upon the three multibarrier concept reports were as follows:

- The production of ceramic pellets by disc pelletization and sintering is a complex process and results in a product of high variability.

- Glass marble nuclear waste forms are technically feasible and offer considerable advantages in quality control.

- Although graphite offers potential for a highly leach-resistant coating process, complications encountered in this study resulted in unacceptable or inferior coatings. 
- The thermal spray systems tested on simulated waste glass marbles (flame spray, wire gun, and plasma spray) produced quality waste form coatings. Metal plasma spray coatings provide the most promising deterrent to water attack.

- Glass marbles encapsulated in a lead matrix offer the most significant improvement in waste form stability of all matrix combinations evaluated.

- Ceramic pellets encapsulated in hot-pressed titanium or $\mathrm{TiO}_{2}$ produce a waste form with good durability except that matrix cracking is a problem with $\mathrm{TiO}_{2}$.

- Graphite offers a distinct potential for use as a matrix or barrier material for the isolation of nuclear waste because of its low reaction rate with water. This potential was not fully realized because the graphite composites could not be made impermeable to water.

In the radiation damage studies report, cesium transmutation was studied by preparing materials containing natural cesium and then irradiating them with neutrons to produce ${ }^{34} \mathrm{Cs}$, which transmutes to ${ }^{134} \mathrm{Ba}$. The properties monitored at about one-year intervals following irradiation were density, leach rate, and microstructure. A small amount of x-ray diffraction work has also been conducted. Small changes in density and leach rate have been observed for some of the terials, but they were not large enough to be of any consequence for the final disposal of high-level wastes.

In the alpha radiation effects section of the radiation damage report, two single-phase crystalline materials, $\mathrm{Gd}_{2} \mathrm{Ti}_{2} \mathrm{O}_{7}$ and $\mathrm{CaZrTi}_{2} \mathrm{O}_{7}$, were studied by doping with ${ }^{244} \mathrm{Cm}$ at the 3 wt $\%$ level. Changes in the crystalline structure measured by $x$-ray diffraction as a function of dose show that damage ingrowth follows an expected exponential relationship of the form $\Delta \mathrm{V} / \mathrm{v}_{0}=$ $A[1-\exp (-B D)]$. In both cases, the materials became $x$-ray amorphous before the estimated saturation value was reached. The predicted magnitudes of the unit cell volume changes at saturation are $5.4 \%$ and $3.5 \%$, respectively, for $\mathrm{Gd}_{2} \mathrm{Ti}_{2} \mathrm{O}_{7}$ and $\mathrm{CaZrTi}_{2} \mathrm{O}_{7}$.

Alternative Waste Form Development - SRL. The development of waste form alternatives to borosilicate glass for the immobilization of SRP high-level waste is a continuing program in support of the Defense Waste Processing Facility (DWPF) project. The objective is to develop by 1983 , one alternative form to a level where a technically defensible comparison can be made with the reference form, borosilicate glass, to support final selection of the DWPF waste form. The program is divided into three major 
subtasks: (1) waste form development and characterization;

(2) process evaluation; and (3) risk assessments for geologic disposal of SRP waste.

\section{- Comparative Leach Test Program}

Partial results of comparative leach tests with borosilicate glass (BSG), SYNROC (SYN), tailored ceramic (TC) and highsilica glass (HSG) forms were reported previously. ${ }^{3}$ These results included chree elements leached from forms containing composite waste sludge. Complete results are now available for seven elements leached from forms with three different simulated waste sludges.

Tables 2 through 8 give the experimental leach rates from 28day MCC-1 tests for cesium, uranium, cerium, sodium, aluminum, iron, and zirconium, respectively. Each waste form contained either composite sludge, which is an average composition of SRP high-level waste, or high-aluminum or high-iron sludges, which represent extreme compositions. Each datum generally is the average and standard deviation of triplicate tests. Three leachants were used: brine, silicate water, and deionized water.

The data show that different forms have the lowest leach rates for different elements, and that none of the forms is clearly superior for all of the key waste radionuclides. The leach rates are generally in the following orders, from best to worst:

For Cs, Na: HSG $<$ BSG $\sim \mathrm{SYN}<\mathrm{TC}$

For U: $\quad$ SYN $<$ TC $<$ BSG $\sim$ HSG

For Al: $\quad$ H.SG $\sim$ SYN $<$ BSG $<$ TC

For Ce, Fe: BSG, TC, SYN, <HSG

For $\mathrm{Zr}$, virtually all of the data are less than detection limits, and no comparisons can be made.

Fur strontium, the neutron activation method used with these tests proved to be insensitive; other analytical methods are being investigated. Strontium leach rates are expected to be especially low for borosilicate glass and tailored ceramic. 
TABLE 2

Cesium Leach Rates of Alternative Waste Forms

MCC-1 Static Leach Test, 28 Days

Cesium Leach Rate, $g /\left(\mathrm{m}^{2}\right)($ day)

$40^{\circ} \mathrm{C}$

DI Water

$$
\begin{gathered}
0.055 \pm 0.003 \\
0.004 \pm 0.001 \\
0.521 \pm 0.022 \\
0.090 \pm 0.015 \\
-
\end{gathered}
$$

$$
\begin{gathered}
0.006 \pm 0.001 \\
0.008 \pm 0.001 \\
3.56 \pm 0.58
\end{gathered}
$$

High-Silica Glass

Tailored Ceramic
SYNROC (with in situ Cs)

High-Iron Sludge

$1.54 \pm 0.03$
$0.03 \pm 0.01$
$5.09 \pm 0.11$
$0.49 \pm 0.38$
$0.91 \pm 0.07$

$0.76 \pm 0.04$

$0.12 \pm 0.01$

$1.08 \pm 0.63$

$0.39 \pm 0.21$

$0.37 \pm 0.02$

$0.44 \pm 0.03$

$0.04 \pm 0.01$

$1.36 \pm 0.52$

$0.24 \pm 0.08$

$0.56 \pm 0.30$

High-Aluminum Sludge

$\begin{array}{llrlll} & & & & \\ \text { Borosilicate Glass } & 0.501 \pm 0.025 & 3.24 \pm 0.25 & 1.08 \pm 0.08 & 1.05 \pm 0.10 \\ \text { High-Silica Glass } & 0.008 \pm 0.004 & 0.04 \pm 0.003 & 0.07 \pm 0.01 & 0.02 \pm 0.003 \\ \text { Tailored Ceramic } & 3.90 \pm 0.93 & 12.56 \pm 0.17 & 4.78 \pm 0.28 & .6 .1 & \pm 1.1 \\ \text { SYNROC (with in situ Cs) } & 0.079 \pm 0.015 & 0.90 \pm 0.06 & 0.45 \pm 0.05 & 0.37 \pm 0.04\end{array}$




\section{TABLE 3}

Uranium Leach Rates of Alternative Waste Forms MCC-1 Static Leach Test, 28 Days

\begin{tabular}{cccc} 
Uranium Leach Rate, $\mathrm{g} /\left(\mathrm{m}^{2}\right)($ day) & & \\
\hline $40^{\circ} \mathrm{C}$ & $90^{\circ} \mathrm{C}$ & $90^{\circ} \mathrm{C}$ & $90^{\circ} \mathrm{C}$ \\
DI Water & DI Water. & Si Water & Brine \\
\hline
\end{tabular}

Composite Sludge

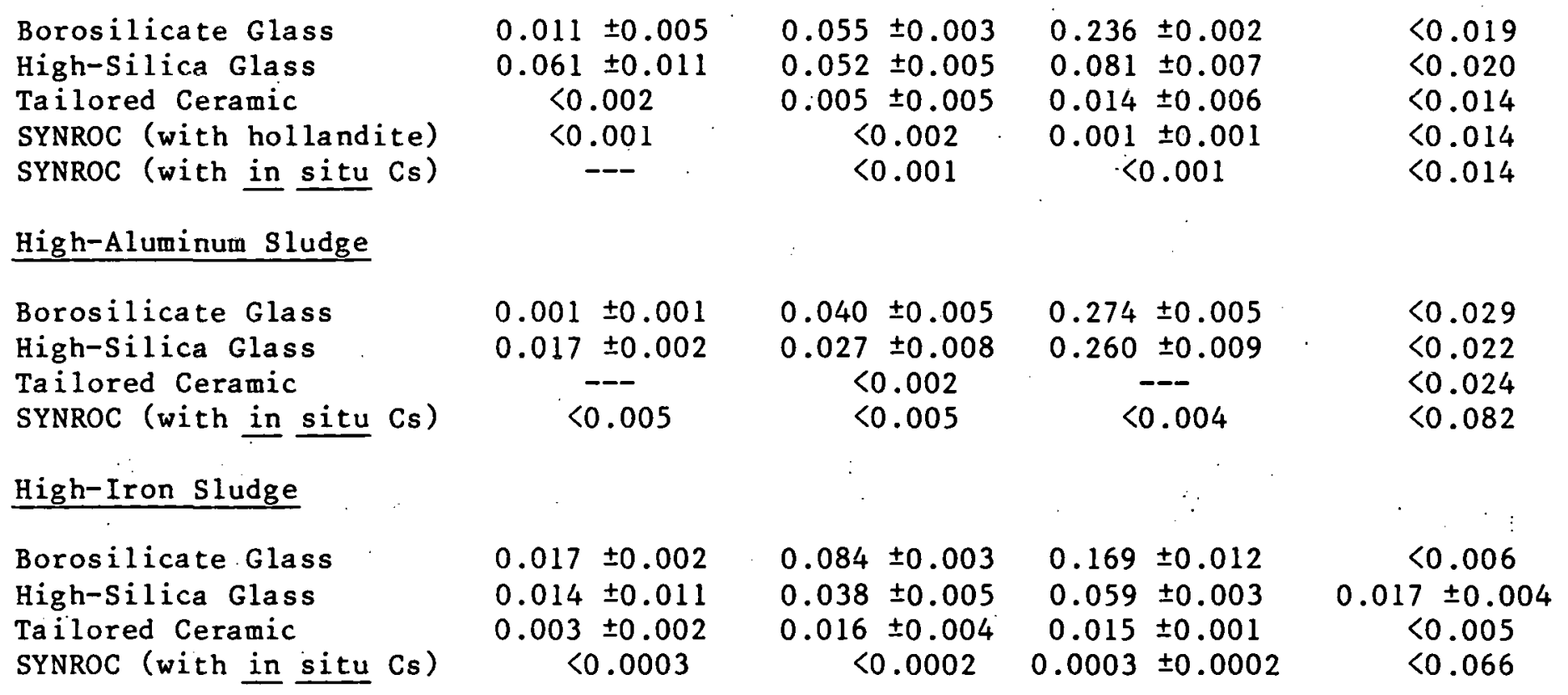


TABLE 4

Cerium Leach Rates of Alternative Waste Forms

MCC-1 Static Leach Test, 28 Days

\begin{tabular}{cccc} 
Cerium Leach Rate, $\mathrm{g} /\left(\mathrm{m}^{2}\right)($ day $)$ & \\
\hline $\begin{array}{c}40^{\circ} \mathrm{C} \\
\text { DI Water }\end{array}$ & $90^{\circ} \mathrm{C}$ & $90^{\circ} \mathrm{C}$ & $90^{\circ} \mathrm{C}$ \\
& DI Water & Si Water & Brine \\
\hline
\end{tabular}

Composite Sludge

Borosilicate Glass

$\begin{array}{cccc}<0.001 & <0.004 & 0.003 \pm 0.001 & <0.029 \\ 0.027 \pm 0.004 & 0.014 \pm 0.004 & 0.015 \pm 0.002 & <0.004 \\ <0.003 & <0.005 & <0.006 & <0.011 \\ 0.001 \pm 0.001 & <0.001 & 0.0009 \pm 0.0001 & <0.007 \\ --- & 0.0016 \pm 0.0004 & <0.001 & <0.034\end{array}$

High-Silica Glass

Tailored Ceramic

SYNROC (with hollandite)

SYNROC (with in situ Cs)

High-Aluminum Sludge

Borosilicate Glass.

High-Silica Glass

Tailored Ceramic

SYNROC (with in situ Cs)

High-Iron Sludge

Borosilicate Glass

High-Silica Glass

Tailored Ceramic

SYNROC (with in situ Cs)

$$
\begin{gathered}
0.003 \pm 0.001 \\
0.014 \pm 0.001 \\
--
\end{gathered}
$$

$0.56 \pm 0.71$

$0.013 \pm 0.005$

$<0.055$

$<0.006$
$<0.020$
$0.0015 \pm 0.0004$
$--$
$<0.008$
$<0.110$
$0.071 \pm 0.033$
$<0.188$
$<0.042$

$<0.041$

$0.055 \pm 0.018$

$<0.016$

$0.005 \pm 0.004$
$<0.027$

$0.002 \pm 0.001$

$<0.004$

$0.0015 \pm 0.0003$
$<0.154$

$0.032 \pm 0.002$

$<0.022$

$0.031 \pm 0.006$ 
TABLE 5

Sodium Leach Rates of Alternative Waste Forms

MCC-1 Static Leach Test, 28 Days

\begin{tabular}{ccc}
\multicolumn{3}{l}{ Sodium Leach Rate, $g /\left(\mathrm{m}^{2}\right)($ day $)$} \\
\hline $40^{\circ} \mathrm{C}$ & $90^{\circ} \mathrm{C}$ & $90^{\circ} \mathrm{C}$ \\
DI Water & DI Water & Si Water \\
\hline
\end{tabular}

Composite Sludge

Borosilicate Glass

High-Silica Glass

Tailored Ceramic

SYNROC (with hollandite)

$$
\begin{array}{ccc}
0.039 \pm 0.004 & 1.64 & \pm 0.06 \\
0.042 \pm 0.004 & 0.11 & \pm 0.03 \\
<<0.026 & 13.4 & \pm 1.6 \\
0.168 \pm 0.038 & 1.3 & \pm 1.1 \\
-- & 0.76 & \pm 0.04
\end{array}
$$

$1.09 \pm 0.07$

$0.46 \pm 0.30$

SYNROC (with in situ Cs)

$11.8 \pm 2.0$

$1.06 \pm 0.34$

$1.42 \pm 0.05$

High-Aluminum Sludge

Borosilicate Glass

$$
\begin{gathered}
0.012 \pm 0.002 \\
0.044 \pm 0.026 \\
<1.07
\end{gathered}
$$

$$
\begin{gathered}
0.54 \pm 0.05 \\
0.08 \pm 0.11 \\
8.41 \pm 0.79 \\
<1.76
\end{gathered}
$$

$0.40 \pm 0.11$

$<0.48$

$<3.25$

High-Iron Sludge

Borosilicate Glass

High-Silica Glass

Tailored Ceramic

$$
\begin{array}{cl}
0.542 & \pm 0.030 \\
0.025 & \pm 0.008 \\
10.05 & \pm 0.06 \\
0.098 & \pm 0.026
\end{array}
$$

$5.84 \pm 0.07$

$0.12 \pm 0.07$

$4.32 \pm 0.11$

SYNROC (with in situ Cs)

$21.6 \pm 1.5$

$<0.82$

$2.83 \pm 0.46$

$16.0 \pm 0.8$

$<0.70$ 


\section{TABLE 6}

Aluminum Leach Rates of Alternative Waste Forms

MCC-1 Static Leach Test, 28 Days

\begin{tabular}{ccc} 
Aluminum Leach & Rate, $\mathrm{g} /\left(\mathrm{m}^{2}\right)($ day $)$ \\
\hline $40^{\circ} \mathrm{C}$ & $90^{\circ} \mathrm{C}$ & $90^{\circ} \mathrm{C}$ \\
DI Water & DI.Water & Si Water \\
\hline
\end{tabular}

Composite Sludge

$\begin{array}{lcccc}\text { Borosilicate Glass } & 0.122 \pm 0.110 & 0.265 \pm 0.035 & 0.216 \pm 0.021 \\ \text { High-Silica Glass } & 0.050 \pm 0.011 & 0.045 \pm 0.024 & 0.087 \pm 0.008 \\ \text { Tailored Ceramic } & 0.116 \pm 0.011 & 0.382 \pm 0.039 & 0.112 \pm 0.017 \\ \text { SYNROC (with hollandite) } & 0.023 \pm 0.012 & 0.205 \pm 0.035 & 0.078 \pm 0.002 \\ \text { SYNROC (with in situ Cs) } & --- & 0.056 \pm 0.034 & 0.110 \pm 0.013\end{array}$

High-Aluminum Sludge

$\begin{array}{lcccc}\text { Borosilicate Glass } & 0.012 \pm 0.001 & 0.346 \pm 0.055 & 0.213 \pm 0.003 \\ \text { High-Silica Glass } & 0.033 \pm 0.008 & 0.029 \pm 0.006 & 0.184 \pm 0.014 \\ \text { Tailored Ceramic } & -- & 0.010 \pm 0.001 & -- \\ \text { SYNROC (with in situ Cs) } & 0.014 \pm 0.004 & 0.037 \pm 0.029 & 0.038 \pm 0.002\end{array}$

High-Iron Sludge

Borosilicate "Glass

High-Silica Glass

$0.635 \pm 0.014$

$0.999 \pm 0.202$

$0.476 \pm 0.027$

Tailored Ceramic

$0.072 \pm 0.021$

$0.097 \pm 0.013$

$0.262 \pm 0.010$

$0.097 \pm 0.027$

$0.422 \pm 0.030$

$0.164 \pm 0.004$

SYNROC (with in situ Cs)

$0.080 \pm 0.018$

$0.326 \pm 0.061$

$0.341 \pm 0.026$ 


\section{TABLE 7}

Iron Leach Rates of Alternative Waste Forms

MCC-1 Static Leach Test, 28 Days

\begin{tabular}{cccc} 
Iron Leach Rate, $g /\left(\mathrm{m}^{2}\right)($ day $)$ & & \\
\hline $40^{\circ} \mathrm{C}$ & $90^{\circ} \mathrm{C}$ & $90^{\circ} \mathrm{C}$ & $90^{\circ} \mathrm{C}$ \\
DI Water & DI Water & Si Water & Brine \\
\hline
\end{tabular}

Composite Sludge

Borosilicate Glass

$<0.0005$

$0.021 \pm 0.009$

$<0.0023$

Tailored Ceramic

SYNROC (with hollandite)

SYNROC (with in situ Cs)

High-Aluminum Sludge

Borosilicate Glass

High-Silica Glass

Tailored Ceramic

SYNROC (with in situ Cs)

High-Iron Sludge

Borosilicate Glass

High-Silica Glass

Tailored Ceramic

SYNROC (with in situ Cs)

$$
\begin{gathered}
<0.010 \\
0.015 \pm 0.002 \\
<0.001
\end{gathered}
$$

$<0.019$

$0.015 \pm 0.011$

$<0.009$

$<0.0005$
$<0.001$

$0.040 \pm 0.013$

$<0.003$

$<0.001$

$<0.001$
$<0.025$

$<0.007$

$<0.011$

$<0.008$

$<0.017$

$<0.001$

$<0.001$

$<0.093$
$0.026 \pm 0.005$
$<0.053$
$0.003 \pm 0.0004$

$<0.034$

$0.051 \pm 0.006$

$-\cdots$.

$<0.002$

$<0.250$

$0.073 \pm 0.020$

$<0.262$

$<0.007$

$<0.151$

$<0.004$

$<0.060$

$<0.007$ 


\section{TABLE 8}

Zirconium Leach Rates of Alternative Waste Forms

MCC-1 Static Leach Test, 28 Days

Zirconium Leach Rate, $g /\left(\mathrm{m}^{2}\right)($ day)

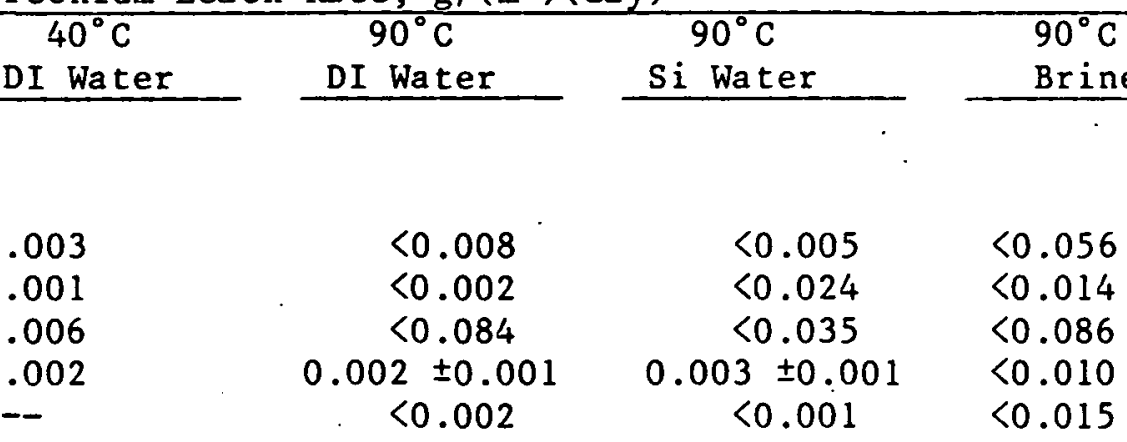

High-Aluminum Sludge

Borosilicate Glass

$<0.004$

$<0.019$

$<0.058$

$<0.113$

$<0.001$

$<0.001$

High-Silica Glass

$---$

SYNROC (with in situ Cs)

$<0.003$

$<0.053$

$<0.005$

$<0.022$

$<0.006$

$<0.006$

$<0.164$

$<0.029$

High-Iron Sludge

Borosilicate Glass

$<0.013$

$<0.025$

$<0.0002$

High-Silica Glass

$<0.010$

$<0.0006$

$<0.013$
$0.006 \pm 0.002$
$<0.011$

$<0.069$

$<0.017$

$<0.018$

Tailored Ceramic

$<0.0003$

$<0.001$

$0.0018 \pm 0.0004$

$<0.069$

$<0.004$ 
The following conclusions may be drawn from the leach rates in Tables 2 through 8 :

1. Borosilicate glass has an intermediate leach rate comparable to SYNROC for $\mathrm{Cs}$ and $\mathrm{Na}$, has a relatively high leach rate for $U$ and $A I$ (although absolute rate is low), and has a lower leach rate than high-silica glass for $\mathrm{Ce}$ and $\mathrm{Fe}$.

2. High-silica glass is best for $\mathrm{Cs}, \mathrm{Na}$, and $\mathrm{Al}$, but has relatively high leach rates for $\mathrm{U}, \mathrm{Ce}$, and $\mathrm{Fe}$.

3. Tailored ceramic has an intermediate ranking for $U$ and $A l$, ranks lowest for $\mathrm{Cs}$ and $\mathrm{Na}$, and is better than high-silica glass for $\mathrm{Ce}$ and $\mathrm{Fe}$.

4. SYNROC ranks highest for $U$ and $A l$, has an intermediate ranking for $\mathrm{Cs}$ and $\mathrm{Na}$, and is better than high-silica glass for $\mathrm{Ce}$ and $\mathrm{Fe}$.

5. Effects of sludge type or leachant on leach rates are generally less than a factor of three.

\section{- Hot-Cell Testing Program}

Preparations for laboratory-scale testing of the ceramic form with actual SRP waste have been deferred until completion of a detailed assessment of the relative environmental and economic impacts of the borosilicate glass and ceramic forms. Resumption of the ceramic form test program at SRL will be dependent on whether the ceramic form offers any significant environmental or economic advantages over borosilicate glass.

Two experimental facilities were being constructed at SRL for the ceiramic test program:

1. A cold waste form development laboratory to develop and demonstrate ceramic fabrication procedures and equipment with simulated (non-radioactive) waste, and

2. Three hot cells in the Shielded Cells Facility to fabricate and test ceramic forms with actual SRP waste. Identical equiprent would be used in the two facilities.

Construction of the cold laboratory was completed this quarter. Two Astro Hot Presses (one for the hot cell facility) were received, but not installed. Renovation of three cells in the SCF was essentially completed, except for completing installation of the. new windows. Mockup of the powder preparation 
equipment for the $S C F$ was about $90 \%$ complete. Construction of a second spray calciner. was stopped, with fabrication about $80 \%$ complete.

Initial tests with simulated waste were performed to demonstrate the various process steps and check out equipment to be used in preparation of the ceramic waste form. The objective of these initial tests was to demonstrate the use of the laboratory-scale spray calciner. Simulated SRP composite sludge was mixed with the appropriate ceramic additives to prepare the reference SYNROC waste mixture for SRP waste, designated S29. This formulation is the starting point for product optimization studies by the ceramic developers (LLNL and RES) and for process scale-up tests by LLNL. The S29 mixture was wet-vibratory milled to produce a slurry with a mean particle size of $1.7 \mu \mathrm{m}(95 \%<3.4 \mu \mathrm{m})$; the slurry was spray calcined in air at about $600^{\circ} \mathrm{C}$; and the calcined powders were then hot pressed into ceramic pellets at $1050^{\circ} \mathrm{C}$ and 4000 psi. One test in the calciner test series involves using $\mathrm{CO} / \mathrm{CO}_{2}(1: 10)$ gas to blanket a heated collection pot under the spray calciner to control the redox state of key elements (iron and uranium).

Thermogravimetric analysis (TGA) of the calcined powders showed that the laboratory-scale spray calciner is effective in removing volatile species ( $\mathrm{NO}_{3}, \mathrm{H}_{2} \mathrm{O}, \mathrm{CO}_{3}$ ) if full atomization of the slurry is achieved. However, frequent problems with the atomizing nozzle were encountered. Examinations after several runs revealed caked deposits (vs. loose powder) on the sides of the collection cone, indicating incomplete atomization. Calcine from these runs showed a TGA weight loss of approximately $8.5 \%$. Calcined powders from the collection cone, prepared with acceptable slurry atomization, showed weight losses of about $2.5 \%$. Subsequent roasting of the calcined powders at $650-750^{\circ} \mathrm{C}$ in a heated pot below the collection cone indicated that no additional volatiles were removed. X-ray diffraction analyses of the calcined powders revealed spinel and anatase peaks; hematite was observed in powders not reheated with $\mathrm{CO} / \mathrm{CO}_{2}$. The hematite was less prevalent in the unheated calcine, showing that subsequent air-roasting further oxidizes the powder. The presence of calcium carbonate in the unheated sample verified that calcination was incomplete. A second calciner test series was initiated to evaluate the effects of using an inert gas $\left(\mathrm{N}_{2}\right)$ during spray calcination.

Calcines were hot pressed at $1050^{\circ} \mathrm{C}$ and $4000 \mathrm{psi}$ for one hour. One batch was also ball milled, then hot pressed at $1100^{\circ} \mathrm{C}$. Three SYNROC D phases were always observed: spinel, nepheline, and perovskite. Zirconolite was generally observed, but this phase often competed with pseudobrookite and a pyrochlore-like 
phase for titanium and zirconium. When perovskite and pseudobrookite peaks were enhanced, spinel and $z$ irconolite content declined. Spinel lattice parameters decreased as the relative amount of this phase declined, indicating that the iron content is the major variable in spinel formation.

Phase content of these pellets was compared to hot-pressed pellets of calcined, untailored simulated sludge. The untailored pellets contained spinel, but also wustite $\left(\mathrm{Fe}_{1-\mathrm{x}} \mathrm{O}\right)$ and nickel metal. Thus, some reduction was caused by pressing in graphite dies. A calcium uranate phase similar to $\mathrm{Ca}_{3} \mathrm{U}_{5} \mathrm{O}_{16.2}$ was also prevalent, showing that uranium remained primarily in the more-soluble $\mathrm{U}^{6+}$ oxidation state, even when iron and nickel were reduced. However, when tailoring additives were present, no phases containing $\mathrm{U}^{6+}$ were observed. Therefore, the crystal-chemical stability of tetravalent uranium within SYNROC $D$ titanate phases has a much stronger effect on cation valences than the overall oxygen fugacity.

- Ceramic Waste Form and Canister for SRP Waste

A conceptual design of a ceramic form and canister, that might be manufactured in the DWPF should a ceramic process be selected, was developed for use in ONWI waste package design studies. The design basis ceramic is the 529 SYNROC form developed by LLNL, which contains about 60 . wt \% waste oxide and 40 wt \% SYNROC additives. Waste loading in actual forms could vary between about 65 wt \% and 40 wt \%.

The SRP ceramic form would be fabricated by a process involving ball milling to intimately mix the waste sludge and SYNROC additives, spray calcination, and hot isostatic pressing the resulting powder in a 3/8-in. thick, type 1020 carbon steel canister to produce a canistered form with final dimensions of 22-in. diameter hy 36-in. long. Three such consolidated ceramic-waste filled canisters would be enclosed in a secondary canister of 3/8-in.-thick 304L stainless steel with the same overall dimensions as the reference borosilicate glass canister. The secondary canister would provide a decontaminated surface.

The resulting canistered ceramic waste form would contain about 3.5 times the quantity of waste sludge that would be incorporated in a borosilicate glass canister. The curie content and heat generation rate of the ceramic and borosilicate glass forms containing 5-year-old sludge and 15-year-old supernate are compared in Table 9. Typical forms would contain older waste and have somewhat lower curie contents. 
TABLE 9

Comparison of Possible Full-Size Ceramic and Glass Waste Forms

Reference SYNROC D

Borosilicate Crystalline

Glass

Glass

Waste loading (wt \%)

28

$60(47) *$

Waste form/canister (lbs)

$-3260$

5300

Waste form density $(g / c c)$

2.75

4.0

Heat generated per canister (watts) (5-yr-old sludge plus 15-yr-old supernate)

423

1472

Radionuclide content, curies per canister

150,000

522,000

Radionuclide content, curies per pound

46

98.4

* With a luminum remova 1 
A report has been drafted which describes the conceptual SRP ceramic form and its expected properties based on LLNL tests with SYNROC D.

\section{- Process Evaluations}

Operating costs for a ceramic-based DWPF were estimated on the basis of a similar operating cost estimate for the reference glass DWPF. The undiscounted operating cost over a 20-year production period for the ceramic process was estimated to be $\$ 764 \mathrm{MM}(\$ 38.2 \mathrm{MM} / \mathrm{yr})$ in 1981 dollars compared to $\$ 448 \mathrm{MM}$ $(\$ 22.4 \mathrm{MM} / \mathrm{yr})$ for borosilicate glass. Operating costs by category are listed in Table 10. Two different estimating methods were used, with excellent agreement obtained between the two sets of costs. Input for the cost estimates included operating histories of SRP reprocessing and interim waste management facilities, DWPF conceptual designs for borosilicate glass and ceramic processes, the processability analys is reported last quarter, and capital cost appraisals for the two facilities. The operating costs will be included in a complete cost study comparing total system costs (production, interim storage, transportation, and geologic disposal) for the two candidate waste forms.

- Repository Risk Assessments

Under a subcontract to SRL, LLNL is assessing the future performance of waste forms containing SRP waste in geologic repositories and estimating the impact of this performance on radiological risks (dose-to-man). Prior work has focused on the development of a computer code, MISER, which analyzes the transport of waste elements along multiple paths through a repository and its overlying geologic medium. This code is being used to estimate dose-to-man from SRP waste and the effects of the waste form on this dose.

Sensitivity.analyses were performed for a "base case" salt repository, assumed to be sandwiched between upper and lower aquifers. Results for a well intrusion at the downstream edge of the repository show that:

1. ${ }^{99} \mathrm{TC}$ is the only radionuclide which would be released to the well within $10^{6}$ years. It peaks between $10^{4}$ and $10^{3}$ years.

2. There is no effect of dissolution rates of the waste form from $10^{-1}$ to about $10^{-5}$ parts/yr. 
TABLE $" 10$

Summary of Estimated Yearly Operating Costs for Ceramic-Based DWPF ( $\$ M M)$

Prod., Maint, E\&I, T\&I

8.8

Area Services (HP, Serv., Power, Proj., Tech., S\&S, Info., etc.)

Total direct salaries \& labor

12.2

General plant overhead a $74 \%$ of prod.

6.5

SRL: Plant assistance @ $20 \%$ of prod.

Total overhead

$\frac{1.8}{8.3}$

Equipment replacement

10.0

Coa 1

0.6

Electricity

2.0

Chemicals

0.9

Misc. supplies e $25 \%$ of prod.

2.2

Total other materials and supplies

5.7

Quality assurance operating costs

2.0

Total

38.2

(a) 20 year production period

764 
3. There is a nearly linear drop-off in peak individual dose for dissolution rates less than about $10^{-5}$ and $10^{-6} / \mathrm{yr}$, but the maximum dose is only a small fraction of natural background.

4. Doses are not sensitive to mean canister failure times over the range 0 to $10^{5}$ years.

A data base was compiled for geologic and waste form parameters and repository design features. Repository characteristics are consistent with published ONWI designs. A reference repository siting model was developed to represent the major features of a flood basalt region. This model includes a shallow surface sediment layer above alternating interbed and basalt layers. Hydrologic data from basalt at the Hanford site have been a ssembled.

The MISER code was modified to include waste transport through more than one shaft from the repository to the upper aquifer, because several shafts may be required for salt. The repository model was improved to better analyze the spatial separation of canisters. Treatment of the waste canisters as an "extended," distributed source of radionuclides results in more realistic doses that can be orders of magnitude less than those generated by more cormon point-source models.

Sol-Gel Technology - ORNL. Several 100-g batches of gel spheres containing simulated commercial power reactor waste, Purex process raffinate, were produced. The spheres corresponded to 5 , 10 , and 20 wt $\%$ waste loadings in a $\mathrm{Fe}_{2} \mathrm{O}-\mathrm{Al}_{2} \mathrm{O}_{3}-\mathrm{ZrO}_{2}-\mathrm{SiO}_{2}$ matrix.

When gel spheres containing Purex raffinate were washed with $0.5 \mathrm{M} \mathrm{NH} \mathrm{NH}_{4} \mathrm{OH}$, the cesium was removed along with soluble impurities. Tests show that it is feasible to sorb cesium onto Ionsiv IE-95 from the used wash solutions. The composition of the used wash solution varies during the wash cycle, but the composite composition of $15 \mathrm{~L}$ of $0.5 \mathrm{M} \mathrm{NH} \mathrm{NH}_{4} \mathrm{OH}$ used to wash $100 \mathrm{~g}$ of $20 \%$ raffinate spheres is $7.5 \times 10^{-4} \mathrm{M} \mathrm{CsNO}_{3}-0.2 \mathrm{M}$ urea - $0.2 \mathrm{M}$ HMTA $-0.2 \mathrm{M} \mathrm{NH}_{4} \mathrm{NO}_{3}-$ $0.3 \mathrm{M} \mathrm{NH}_{4} \mathrm{OH}$. Ionsiv $\overline{\mathrm{IE}}-95$ has a cesium distribution coef $\overline{\mathrm{f}}$ icient (mg Cs/g zeolite)/(mg Cs/mL solution) of 450 at low loadings and a saturation cesium loading of $12 \mathrm{mg} \mathrm{Cs} / \mathrm{g}$ from a simulated wash solution of the above composition. Tests showed that variations in the urea, HMTA, and $\mathrm{NH}_{4} \mathrm{OH}$ concentrations did not affect cesium loading. The cesium distribution coefficient was reduced from 170 to 40 when the $\mathrm{NH}_{4} \mathrm{NO}_{3}$ concentration was increased from $0.2 \mathrm{M}$ to $0.8 \mathrm{M}$. Tests need to be made to determine the variation in the $\mathrm{NH}_{4} \overline{\mathrm{NO}}_{3}$ concentration during the wash cycle. 
The first draft of a report describing the preparation of gel spheres from radioactive waste sludges and simulated Purex raffinate is being written. A paper entitled "Preparation of Gel Spheres Containing Simulated High-Level Radioactive "Waste" is being processed for publication in Radioactive Waste Management. An oral presentation entitled "Incorporation of High-Level Nuclear Waste in Gel Spheres" was presented at the American Ceramic Society Fall Meeting of the Nuclear Division-Pacific Cuast Region in Newport Beach, California.

One-hundred gram batches of gel spheres containing 5, 10, and 20 wt \% loading of Purex raffinate having final compositions similar to the $90 / 10$ ( 90 wt \% SRP, 10 wt \% $\mathrm{ZrO}_{2}$ ) were dried and sintered. The spheres were sintered to $1000^{\circ} \mathrm{C}$ in an $\mathrm{Ar}-4 \%$ hydrogen atmosphere to stabilize the spheres for coating. $X$-ray diffraction and density measurements were made and are being a na lyzed.

The sintering behavior of particles can now be determined using a recently installed optical microscope with high temperature hot stage. This method improves on the push rod type dilatometers in that no force is applied to the spheres.

The elemental composition of the various types of sintered waste forms which we have produced during the past year have been determined, and the data are being sumnarized. Samples of sintered material have also been mechanically thinned. The samples will be ion-milled in order to obtain thin specimens to be used for phase analyses by the transmission electron microscopy tecluique.

Neutron Activation and Tracer Studies - ANL. The general objective of this program is to develop techniques and qualify methods that utilize neutron activation analysis (NAA) and radioactive tracers for characterizing simulated waste forms. Comparison of characterization test results obtained using these two methods and with other existing characterization data will be used to specify conditions under which such tests and the resulting data may be extrapolated to fully radioactive specimens. The current focus is on leach-rate characterizations of simulated waste glasses and, to a lesser extent, advanced waste forms.

Major goals are completion of the development of the NAA method for leach-rate determinations, definition of the accuracy, sensitivity, and limitations of NAA and establishment of the applicability of the test results to larger-scale waste forms. Similar goals exist for the development of methods for radioactive tracers. 
- Radioactive Tracer Method Qualification

A series of experiments was completed that qualifies the use of NAA and radioactive tracers to measure the leach rates from SRL frit 131 and SRL frit 211 simulated waste glasses. Four classes of chemical elements present as minor ( $<5$ wt \%) elements in SRL defense wastes and of concern to radioactive waste management have been the focus of the measurements. The four classes are alkali metals (Cs), alkaline earths ( $\mathrm{Sr}$ and $\mathrm{Ba}$ ), rare earths (Ce, Eu) and noble metals ( $\mathrm{Ru}$ ). Simulated waste glass containing radioactive tracers has been prepared; this glass was leached directly and also submitted for neutron activation prior to leaching. Leach rates were measured wherever possible using four different techniques: (1) conventional chemical solution analyses of leachates from non-neutron activated glass using either Inductively Coupled Plasma Spectroscopy (ICP), Atomic Absorption Spectroscopy (AA), Direct Current Plasma Spectroscopy (DCP), or Flame Emission Spectroscopy, (2) $\gamma$-ray spectroscopy analyses of leachate solutions from a neutron-activated glass specimen (A), (3) $x$-ray spectroscopy analyses of leachate solutions from a glass specimen containing radioactive tracers ( $S$ ), (4) $x$-ray spectroscopy analyses of leachate solutions from a neutron activated glass specimen containing radioactive tracers (S/A).

The objective of these measurements was to obtain comparative leach rate data in order to define the reproducibility, sensitivity, limitations, and precision of leach rate measurements from the various methods.

- Leaching Characterizations of Defense Glass

To qualify the spike/leach method, tests were done on four different glasses: SRI. 211**, SRL 211***, SRL 131, and SRL $131^{*}$. For each type of glass, the leach rates obtained with spiked glass will be compared to those obtained from another method. All the leach tests except those of 362-day duration have been completed. Surface analytical studies of the leached glasses are being performed and will be correlated with the solution analysis results. The data are being compiled and will be piesented as a topical report.

- Leaching Characterizations of Commercial Glass

PNL 76-68 glass is the most studied of commercial waste glasses, and a batch of PNL 76-68 glass was made containing uranium, actinides, and radiotracer spikes. Leach tests are being performed on this glass to establish a base leaching behavior under static MCC-1 test conditions and to compare rare 
earth and actinide leach rates to see if rare earths can act as a stand-in for actinides. Preliminary results are available for 3,7 , and 15 days exposure.

The radiotracers added to the glass are ${ }^{85} \mathrm{Sr},{ }^{133} \mathrm{Ba},{ }^{137} \mathrm{Cs}$, $141 \mathrm{Ce}$, and ${ }^{152} \mathrm{Eu}$ and leaching behavior of these elements is being evaluated using $\gamma$-ray spectroscopy. Actinides added to the glass are ${ }^{239} \mathrm{Pu}, 237 \mathrm{~Np}$, and ${ }^{241} \mathrm{Am}$ and these are being analyzed using $\alpha$-counting.

The $\gamma$-counting procedure is that used in previous radiotracer studies and through 14 days ${ }^{85} \mathrm{Sr}, 133 \mathrm{Ba}$, and ${ }^{137} \mathrm{Cs}$ can be detected in the leachates. However, ${ }^{13^{3}} \mathrm{Cs}$ is present in the original glass at too low a level to be detected in the solid, so cesium leach rates will. have to be back-calculated using atomic absorption values for cesium that will be done on the 28-day samples. Matrix elements and uranium will be analyzed later, if necessary.

- Preliminary Alpha Spectrum Analysis of Glass Leachates

A portion of the leachate from a MCC-1 leach test ( 7 days in deionized water at $90^{\circ} \mathrm{C}$ ) of PNL 76-68 glass containing radioactive tracers and actinides was prepared as an alpha source. The purpose was to examine analytical detection and resolution capabilities for the alpha-emitting actinides with our existing equipment and initial alpha source preparations. The procedure used heat-lamp evaporation onto a $11 / 8-i n$. stainless planchet, tollowed by flaming in a Meker burner to $f i x$ the actinides to the planchet. The high-resolution alpha spectrum from this test resolved three alpha groups that were identified as $237 \mathrm{~Np}$, ${ }^{239} \mathrm{Pu}$, and ${ }^{241} \mathrm{Am}$. The ratios of these alpha intensities relative to the ${ }^{241} \mathrm{Am}$ were $83.7 \pm 5.1,3.3 \pm 0.2$, and 1.0 . For comparison an alpha spectrum taken from an aliquot of the initial starting mixture of the ${ }^{237} \mathrm{~Np}, 239 \mathrm{Pu}$, and ${ }^{241} \mathrm{Am}$ put into the PNL 76-68 glass, indicated relative intensities of the a lpha groups relative to ${ }^{241} \mathrm{Am}$ as $0.10 \pm 0.1,3.0 \pm 0.1$, and 1.0 . The data for both of these spectra are summarized in Table 11 .

From comparison of the alpha spectra data, it is obvious the $237 \mathrm{~Np}$ leaches from the glass at a much faster rate than either the ${ }^{239} \mathrm{Pu}$ or ${ }^{241} \mathrm{Am}$. These data suggest the rate is about $10^{3}$ times faster. The ${ }^{239} \mathrm{Pu}$ and ${ }^{241} \mathrm{Am}$ are leaching at virtually the same rate and these two actinides are easily measurable in this initial seven-day test. Leach tests for longer periods than seven days should also permit measurements of the leach rates of $237 \mathrm{~Np}, 239 \mathrm{Pu}$, and ${ }^{241} \mathrm{Am}$. 
The preliminary analysis concludes that measurements of alpha leach rates of ${ }^{237} \mathrm{~Np},{ }^{239} \mathrm{Pu}$, and ${ }^{241} \mathrm{Am}$ are possible for PNL 76-68 glass. Techniques of source preparation for counting will need to be refined to achieve reproducible and standardized analyses. Techniques for dissolving portions of the actinide-containing glass of known.masses and preparing alpha sources will also need to be defined to establish the fractions leached. The same source preparation techniques and data, if coupled with statistical sampling, can be used to verify sample homogeneity and provide additional sensitivity and resolution not available with the autoradiographic techniques.

\section{- Auxiliary Leaching Studies}

One subject to be addressed in the current program for Savannah River Laboratory is the use of NAA in measuring the leaching from crystalline waste forms. This problem was addressed by doing a set of MCC-1 leach tests on SYNROC (MSD-XB93). This SYNROC contains $10 \%$ waste additives $(P W-4 b)$ and provides a spectrum of activation products suitable for $\gamma$-ray analysis.

The test procedure was to do a MCC-1 test set on activated SYNROC and the same set on non-activated SYNROC. The activated SYNROC leachates would be analyzed with $\gamma$-ray counting and ICP/AA spectroscopy, and the non-activated SYNROC leachates would be analyzed with ICP/AA spectroscopy. From these analyses it would be possible to compare the leach rates of waste and matrix elements in both activated and nonactivated samples, thus determining whether neutron activation of the solid affects the leaching process.

\section{TABLE 11}

\section{Summary of Alpha Spectra Analyses of Actinides Added to PNL 76-68 Glass}

\begin{tabular}{|c|c|c|c|c|c|}
\hline \multicolumn{2}{|l|}{ Sample ID } & \multirow{2}{*}{$\frac{\text { Isotope }}{2{ }^{37} \mathrm{~Np}}$} & $\begin{array}{c}\text { Area } \\
\text { (Counts) } \\
\end{array}$ & \multirow{2}{*}{$\frac{\begin{array}{l}\text { Live Count Time } \\
(\sec s)\end{array}}{163470}$} & \multirow{2}{*}{$\begin{array}{l}\text { Radio } \\
\text { Ac/Am } \\
83.7\end{array}$} \\
\hline Leachate: & 7 days & & $35000 \pm 200$ & & \\
\hline & & ${ }^{239} \mathrm{Pu}$ & $1400 \pm 40$ & 163470 & 3.3 \\
\hline & & $241 \mathrm{Am}$ & $418 \pm 20$ & 163470 & 1.0 \\
\hline \multirow{2}{*}{\multicolumn{2}{|c|}{$\begin{array}{c}\text { Starting glass } \\
\text { composition }\end{array}$}} & $237 \mathrm{~Np}$ & $3415 \pm 60$ & 2732 & 0.1 \\
\hline & & $23{ }^{9} \mathrm{Pu}$ & $98400 \pm 300$ & 2732 & 3.0 \\
\hline & . & $241 \mathrm{Am}$ & $33060 \pm 200$ & 2732 & 1.0 \\
\hline
\end{tabular}


The leaching conditions used in this test are given in Table 12 and the results in Table 13. All tests except L-488 and L-497 have been completed and all activated leachates have been analyzed with $\gamma$-ray counting. To complete this project, as designed, it will be necessary to do ICP and cesium (AA) analyses on 19 samples ( 10 radioactive, 9 cold). Two problems currently exist in completing this work: (1) there is no money for the analyses, and (2) there is no ICP available to do the analyses. The unanalyzed leachates have been acidified and are being stored.

When completed these leach studies will provide SRL with independent documentation as to the suitability of NAA for measuring leach rates from SYNROC.

\section{- Weathering Studies}

Weathering studies designed to produce weathered (hydrated) glass samples are continuing. Samples of PNL 76-68 glass, SRL frit 211 and SRL $211 *$ are being weathered at $80^{\circ} \mathrm{C}$ and $90 \%$ relative humidity. The weathered samples will provide a description of the hydration process and when subjected to leaching conditions will be used to demonstrate the durability of hydrated glass.

In addition, an experimental plan has been drafted for glass hydration experiments for other conditions. These hydrated glasses will then be characterized for leaching.

Brittle Fracture Studies - ANL. The resistance of solid brittle radioactive waste forms to dispersion from mechanical impacts received during normal and accidental handing conditions of processing, interim storage and transportation is a property of importance. A brittle fracture methodology has been partially developed which relates the impact-stress distribution to the lognormal size distribution of the particles resulting from impact fracture. The practical application for such a fracture model is for the prediction of both the total fracture-surface area and the mass of particles of respirable sizes produced in impact fractures. Development and preliminary verification of this model has been provided by laboratory-scale tests of impacts of reference glass and ceramic specimens and by analyses of data available in the technical literature on impacts of various brittle materials and of large-scale simulated waste-glass canisters. Examination of the validity and utility of this brittle-fracture methodology has been made for a range of laboratory-scale impact conditions and for various solid waste materials. The experimental results have been used to establish preliminary correlations of lognormal 
TABLE 12

Leaching Conditions for NAA SYRROC

\begin{tabular}{|c|c|c|c|c|c|c|c|c|}
\hline Sample & $\begin{array}{c}\text { Sample } \\
\text { No. } \\
\end{array}$ & $\begin{array}{l}\text { Temp } \\
\left(\mathrm{(}^{\circ} \mathrm{C}\right) \\
\end{array}$ & $\begin{array}{c}\text { Time } \\
\text { (days) } \\
\end{array}$ & $\begin{array}{c}\text { Mass } \\
\text { Sample } \\
\text { (gm) } \\
\end{array}$ & $\begin{array}{c}\Delta \text { Mass } \\
\left(\mathrm{gm} \times 10^{-4}\right) \\
\end{array}$ & $\begin{array}{l}\mathrm{SA} \\
\left(\mathrm{cm}^{2}\right) \\
\end{array}$ & $\begin{array}{l}\text { Fina } 1 \\
\mathrm{pH}^{\mathrm{H}} \\
\end{array}$ & $\begin{array}{l}\text { Fi na l } \\
\text { Leachate } \\
\text { Volume } \\
\quad(\mathrm{ml}) \\
\end{array}$ \\
\hline SYNROC XB93 & $L-482$ & 90 & 3 & 0.2051 & 1 & 1.914 & 5.9 & 18.44 \\
\hline \multirow[t]{6}{*}{$\begin{array}{l}\text { activated } \\
T_{0}=9 / 25 / 81\end{array}$} & $\begin{array}{l}L-483 \\
L-484\end{array}$ & $\begin{array}{l}90 \\
90\end{array}$ & $\begin{array}{r}7 \\
14\end{array}$ & $\begin{array}{l}0.2295 \\
0.2298\end{array}$ & $\begin{array}{l}1 \\
0\end{array}$ & $\begin{array}{l}1.861 \\
1.895\end{array}$ & $\begin{array}{l}6.7 \\
6.8\end{array}$ & $\begin{array}{l}17.88 \\
18.36\end{array}$ \\
\hline & $\begin{array}{l}L-485 \\
L-486\end{array}$ & $\begin{array}{l}90 \\
90\end{array}$ & $\begin{array}{l}28 \\
28\end{array}$ & $\begin{array}{l}0.2763 \\
0.2881\end{array}$ & $\begin{array}{l}1 \\
2\end{array}$ & $\begin{array}{l}1.916 \\
1.936\end{array}$ & $\begin{array}{l}7.5 \\
7.2\end{array}$ & $\begin{array}{l}17.68 \\
18.05\end{array}$ \\
\hline & $\begin{array}{l}L-487 \\
L-488\end{array}$ & $\begin{array}{l}90 \\
90\end{array}$ & $\begin{array}{r}28 \\
\text { ext }\end{array}$ & $\begin{array}{l}0.2648 \\
0.2825\end{array}$ & 0 & $\begin{array}{l}1.890 \\
1.923\end{array}$ & 7.7 & 17.14 \\
\hline & $L-489$ & 200 & 28 & 0.2639 & 2 & 1.896 & 7.4 & 15.31 \\
\hline & $L-490$ & 40 & 28 & 0.1316 & 0 & 1.758 & 6.2 & 17.01 \\
\hline & $L-491$ & 40 & 28 & 0.2746 & 3 & 1.913 & 6.5 & 18.75 \\
\hline SYNROC XB93 & $L-492$ & 90 & 3 & 0.2527 & 0 & 1.896 & 6.0 & 18.64 \\
\hline \multirow[t]{3}{*}{ nonactivated } & $\begin{array}{l}L-493 \\
L-494\end{array}$ & $\begin{array}{l}90 \\
90\end{array}$ & $\begin{array}{r}7 \\
14\end{array}$ & $\begin{array}{l}0.2271 \\
0.2596\end{array}$ & $\begin{array}{r}+1 \\
1\end{array}$ & $\begin{array}{l}1.847 \\
1.911\end{array}$ & 7.2 & $\begin{array}{l}17.59 \\
18.45\end{array}$ \\
\hline & $\begin{array}{l}L-495 \\
L-496 \\
L-497\end{array}$ & $\begin{array}{l}90 \\
90 \\
90\end{array}$ & $\begin{array}{r}28 \\
28 \\
\text { ext }\end{array}$ & $\begin{array}{l}0.3211 \\
0.2295 \\
0.2566\end{array}$ & $\begin{array}{r}+1 \\
0\end{array}$ & $\begin{array}{l}1.976 \\
1.858 \\
1.900\end{array}$ & $\begin{array}{l}7.2 \\
7.8\end{array}$ & $\begin{array}{l}18.74 \\
17.35\end{array}$ \\
\hline & $\begin{array}{l}L-498 \\
L-499 \\
L-500\end{array}$ & $\begin{array}{r}200 \\
40 \\
40\end{array}$ & $\begin{array}{l}28 \\
28 \\
28\end{array}$ & $\begin{array}{l}0.2591 \\
0.2617 \\
0.2443\end{array}$ & $\begin{array}{l}0 \\
1 \\
0\end{array}$ & $\begin{array}{l}1.893 \\
1.907 \\
1.884\end{array}$ & $\begin{array}{l}7.2 \\
6.4 \\
5.8\end{array}$ & $\begin{array}{l}15.18 \\
18.61 \\
18.64\end{array}$ \\
\hline
\end{tabular}

TABLE 13

Leaching Results for RAA STRROC

\begin{tabular}{|c|c|c|c|c|c|c|c|}
\hline \multirow{3}{*}{$\begin{array}{l}\text { Sample } \\
\text { No.. }\end{array}$} & \multirow{3}{*}{$\begin{array}{l}\text { Temp } \\
\left(\left(^{\circ} \mathrm{C}\right)\right. \\
\end{array}$} & \multirow{3}{*}{$\begin{array}{c}\text { Time } \\
\text { (days) } \\
\end{array}$} & \multicolumn{5}{|c|}{$(\mathrm{NL})_{\mathrm{i}}{ }^{a}, \mathrm{gm} / \mathrm{m}^{2}$} \\
\hline & & & \multicolumn{2}{|c|}{$131 \mathrm{Ba}$} & \multicolumn{2}{|c|}{$134 \mathrm{Cs}$} & \multirow{2}{*}{$\frac{124 \mathrm{Sb}}{1691}$} \\
\hline & & & 123 & 497 & 795 & 1037 & \\
\hline $\begin{array}{l}\mathrm{L}-482 \\
\mathrm{~L}-483 \\
\mathrm{~L}-484\end{array}$ & $\begin{array}{l}90 \\
90 \\
90\end{array}$ & $\begin{array}{r}3 \\
7 \\
14\end{array}$ & $\begin{array}{l}3.3 \\
5.8 \\
2.6\end{array}$ & $\begin{array}{l}2.2 \\
3.5 \\
2.1\end{array}$ & $\begin{array}{l}5.3 \\
8.3 \\
9.9\end{array}$ & $\begin{array}{l}4.8 \\
8.2 \\
8.8\end{array}$ & $\begin{array}{l}13.0 \\
13.6\end{array}$ \\
\hline $\begin{array}{l}L-485 \\
L-486\end{array}$ & $\begin{array}{l}90 \\
90\end{array}$ & $\begin{array}{l}28 \\
28\end{array}$ & $\begin{array}{l}2.9 \\
4.4\end{array}$ & $\begin{array}{l}1.7 \\
2.9\end{array}$ & $\begin{array}{l}14.4 \\
12.9\end{array}$ & 12.2 & $\begin{array}{l}12.6 \\
12.2\end{array}$ \\
\hline $\begin{array}{l}L-487 \\
L-489\end{array}$ & $\begin{array}{r}90 \\
200\end{array}$ & $\begin{array}{l}28 \\
28\end{array}$ & $\begin{array}{r}4.7 \\
12.2\end{array}$ & $\begin{array}{l}3.3 \\
6.6\end{array}$ & $\begin{array}{l}13.7 \\
79.4\end{array}$ & $\begin{array}{l}12.4 \\
73.1\end{array}$ & 10.8 \\
\hline $\begin{array}{l}L-490 \\
L-491\end{array}$ & $\begin{array}{l}90 \\
90\end{array}$ & $\begin{array}{l}28 \\
28\end{array}$ & $\begin{array}{l}2.5 \\
3.0\end{array}$ & $\begin{array}{l}1.9 \\
1.9\end{array}$ & $\begin{array}{l}0.7 \\
0.8\end{array}$ & $\begin{array}{l}0.6 \\
.0 .7\end{array}$ & $\begin{array}{r}9.4 \\
10.6\end{array}$ \\
\hline
\end{tabular}

a. Normalized leach rates for each element are present as a function of the $\gamma$-ray energy used in analysis, e.g., 123 is $123 \mathrm{keV}$. 
size-distribution parameters, fracture surface areas, and material strength properties of brittle-waste forms of various sizes and configurations.

\section{- Experimental Results of an Axial Impact with a Mechanical Stop}

In the previous report, ${ }^{3}$ the particle-size distribution formed in an axial impact was compared with diametral impacts for Pyrex cylinders $(2.5 \mathrm{~cm} \times 2.5 \mathrm{~cm})$ impacted at an energy density of $10 \mathrm{~J} / \mathrm{cm}^{3}$ by our standard impact procedure. No significant difference was found in the fracture results of these two different impact configurations. In the present period, a similar axial impact test was made with a mechanical stop which prevented the dropped weight from coming to rest on the fracture particulate. The use of such a mechanical stop is part of the preliminary recommendations of the Materials Characterization Center (MCC) at the Pacific Northwest Laboratory (PNL). The MCC is charged with developing a standard test for characterizing the impact resistance of solid waste forms.

In the proposed MCC test, a mechanical stop is specified such that the axially-impacted cylindrical specimen can be compressed no more than $40 \%$ of the cylinder height. ${ }^{4}$ The actual selection of the maximum fractional amount of linear compression (i.e., maximum strain) permitted by the stop is somewhat arbitrary. Clearly, if the allowed strain is too small, the characteristic particulate fracture cannot take place, because the impact force will mostly be taken up by the mechanical stop. The general intent of the stop is to allow impact

- racluse lu lake place ds a sesull of lle elaslic cumpiessiun, without any secondary crushing effect that might be incurred by the falling weight coming to rest on the fragments. In our experimental test, a maximum linear compression strain of $25 \%$ was allowed. This was provided by a stop consisting of a type 304 stainless steel ring (76-mm inside diameter and 19.0-mm height) ade of 3-in. standard (schedule 40) pipe. The axially impacted Pyrex specimen $(2.5 \mathrm{~cm}$ by $2.5 \mathrm{~cm}$ ) was centrally located within this ring, and the impact carried out under standard conditions in the bellows impact chamber and with the 10-kg falling weight.

The particle-size distribution of the axial impact test of Pyrex glass with this mechanical stop is shown in Figure 1, along with the results of a comparable test made without the stop. No difference is shown for the smaller-sized particles, including the respirable fraction, consisting of all particles less than $10 \mu \mathrm{m}\left(10^{-5} \mathrm{~m}\right)$ in diameter. The cumulative volume (mass) fractions are slightly less for the test with the stop for particle sizes of about $0.1 \mathrm{~mm}$ and larger. The general shape of the size distributions is the same.

$$
-40-
$$




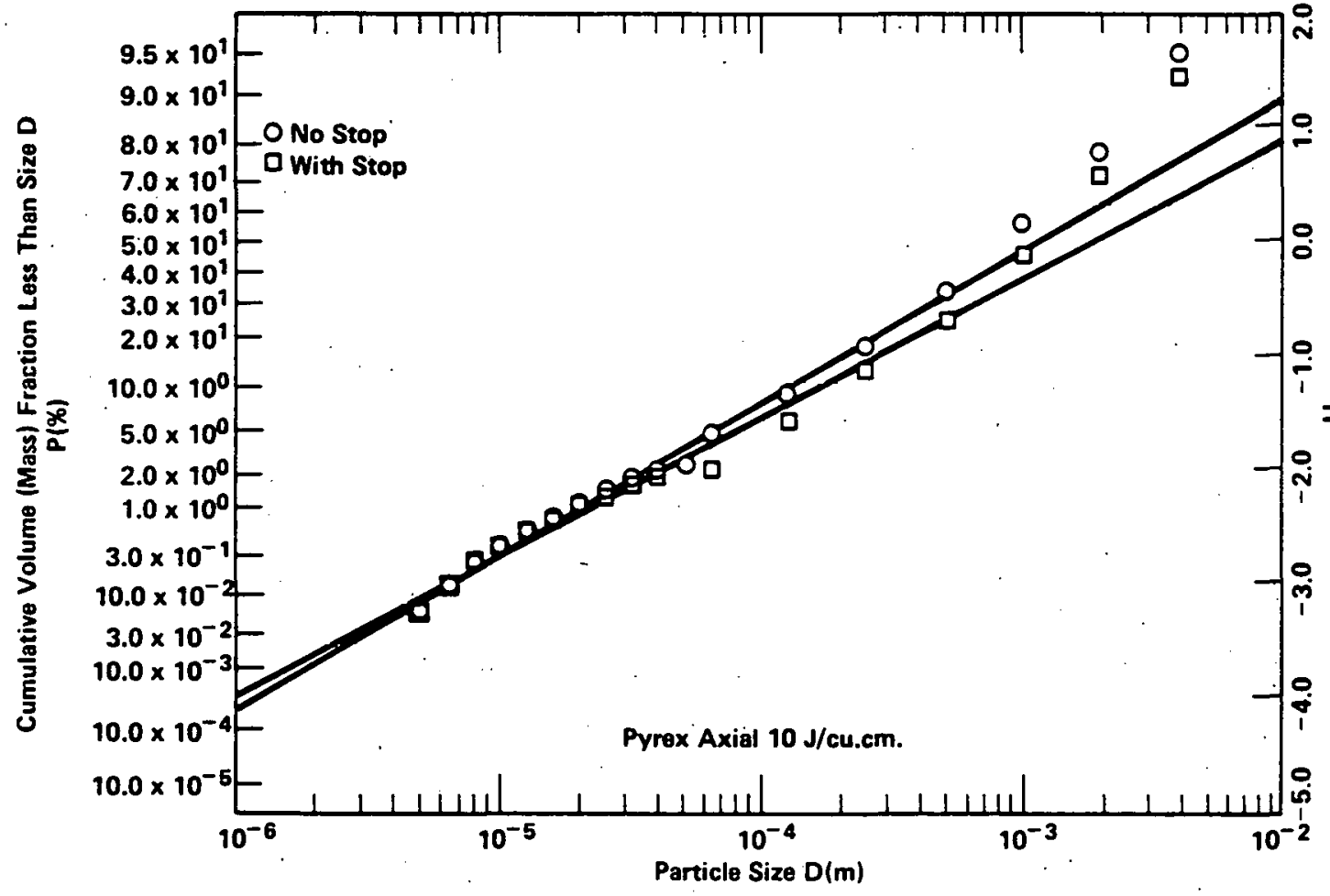

FIGURE 1. Particle Size Distributions for Axial Impacts of Pyrex with and without a Mechanical Stop 
The lognormal parameters determined for the particle-size data are shown in Table 14. The respirable fractions are the same and the particle diameter corresponding to $98 \%$ of the total surface area is the same. The test with the stop showed a somewhat larger standard deviation $\left(\sigma_{g}\right)$ and a somewhat smaller mean diameter $\left(D_{g}\right)$, than the impact without a stop.

The fact that the respirable fraction and the surface-area distribution of the particulates were essentially the same indicates that the presence of the stop did not change the fracture process and did not alter the results of practical concern, namely, the amount of surface area and of respirable particles. These results are consistent with our previous analysis of impact fracture of brittle materials, namely that fracture results depend only on the input energy density of compression and are not sensitive to the velocity of impact per se, nor are they sensitive to the actual (and varying) stress distribution during the compression stage of impact. In other words, the kinetic energy of impact is essentially completely converted into elastic strain energy before fracture begins, and the impact-fracture process is a very rapid disintegration consisting (in effect) of multiple stages of binary cleavage.

TABLE 14

Lognormal Parameters for Axial Impact of Purex With and.Without a Mechanical Stop

\begin{tabular}{|c|c|c|}
\hline Parameter, Units & $\begin{array}{l}\text { Without } \\
\text { Stop }\end{array}$ & $\begin{array}{l}\text { With } \\
\text { Stop }\end{array}$ \\
\hline Respirable fraction, $\mathrm{P}(10 \mu \mathrm{m}), \%$ & $0.30 \pm 0.10$ & $0.29 \pm 0.09$ \\
\hline Standard deviation, $\sigma_{g}$, dimensionless & $5.6 \pm 0.3$ & $6.7 \pm 0.5$ \\
\hline $\begin{array}{l}\text { Geometric mean diameter } \mathrm{D}_{\mathrm{g}} \\
\text { (mass distribution), } \mathrm{mm}\end{array}$ & $1.1 \pm 0.4$ & $1.9 \pm 0.8$ \\
\hline $\begin{array}{l}\text { Geometric mean diameter } \mathrm{D}_{\mathrm{ga}} \\
\quad(\text { surface area distribution), } \mathrm{mm}\end{array}$ & 0.06 & 0.05 \\
\hline $\begin{array}{l}\text { Diameter, (upper-1imit for } 98 \% \\
\text { of surface area, } D_{985} \text { ), mm }\end{array}$ & 2. & 2. \\
\hline
\end{tabular}


- Particle Size Distribution in Full-Scale Impact Tests Reported for Waste-Glass Canisters

A PNL report ${ }^{5}$ describes the results obtained in a study of the fracturing of simulated high-level waste glass in canisters. The fracturing resulted in two cases from free-fall impacts from 9.0 and 30 meters and in 5 other cases by thermal stresses induced by cooling the glass from the molten state. Particle sizes were measured by sieving in three cases and empirical $\log -\log$ plots were made; the plot for the 30 meter impact is shown in Figure 2. The empirical size data for the most highly fractured zones (bottom zone; first $25 \mathrm{~mm}$ from the wall) in the two impact cases are replotted on lognormal coordinates in Figure 3; the data points follow a straight-line lognormal distribution for all particles smaller than about $2 \mathrm{~mm}$. The straight lines show approximately the same slope and the same geometric standard deviation, $\sigma_{\mathrm{g}}=8.7$. The geometric means are: 30-m drop, $D_{g}=1.5 \mathrm{~mm} ; 9-m$ drop, $D_{g}=2.6 \mathrm{~mm}$.

For lognormal particulates, the distribution of the surface area can be calculated from this measured cumulative mass fraction. That is, $98 \%$ of the total surface area is contained in the particles with sizes smaller than $D_{98}$, and the ratio $\mathrm{D}_{98 \mathrm{~s}} / \mathrm{D}_{\mathrm{g}}$ is calculated from $\sigma_{\mathrm{g}}$ :

$$
\frac{\mathrm{D} 98}{\mathrm{D}_{\mathrm{g}}}=\sigma_{\mathrm{g}} 2-1 \mathrm{n} \sigma \mathrm{g}=0.70
$$

Thus, the lognormally distributed particulate ( $<<2 \mathrm{~mm})$ contains almost $98 \%$ of the total surface area, just as in small-scale drop-weight tests.

The report cited $^{5}$ explicitly stated that the size distributions were not lognormal. This statement may have been made because of the departures from lognormality for particles larger than $2 \mathrm{~mm}$, as shown in Figure 2, or because the fractured material as a whole had more than one mode of fracture due to the particular stress distribution. It is generally found that the fracture particulate proper, which contains nearly all the fracture-surface area is lognormally distributed, while some portions of the impacted glass body do not show this particulate mode of fracture, probably because of the uneven stress distribution during the impact-fracture process. The empirical cumulative mass fraction for particules of sizes larger than $\mathrm{D}_{98 s}$ (defined above) is dominated by this residual amount of material, which has a different size distribution than the lognormal fracture particulate proper. Thus, the complete size 


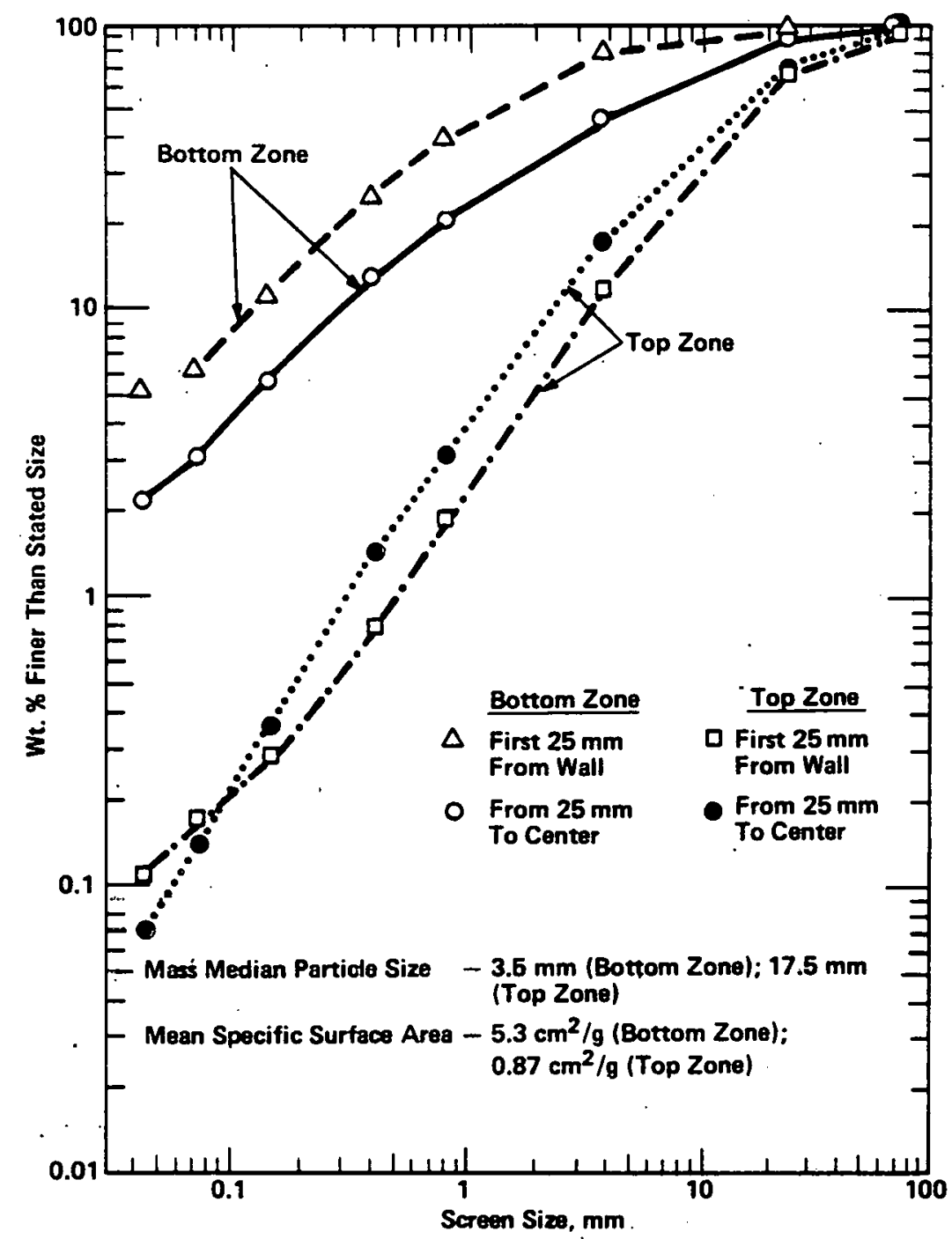

FIGURE 2. Particle Size Distribution for Various Axial Positions in 40-cm-dia Canister Dropped from 30-m Height 


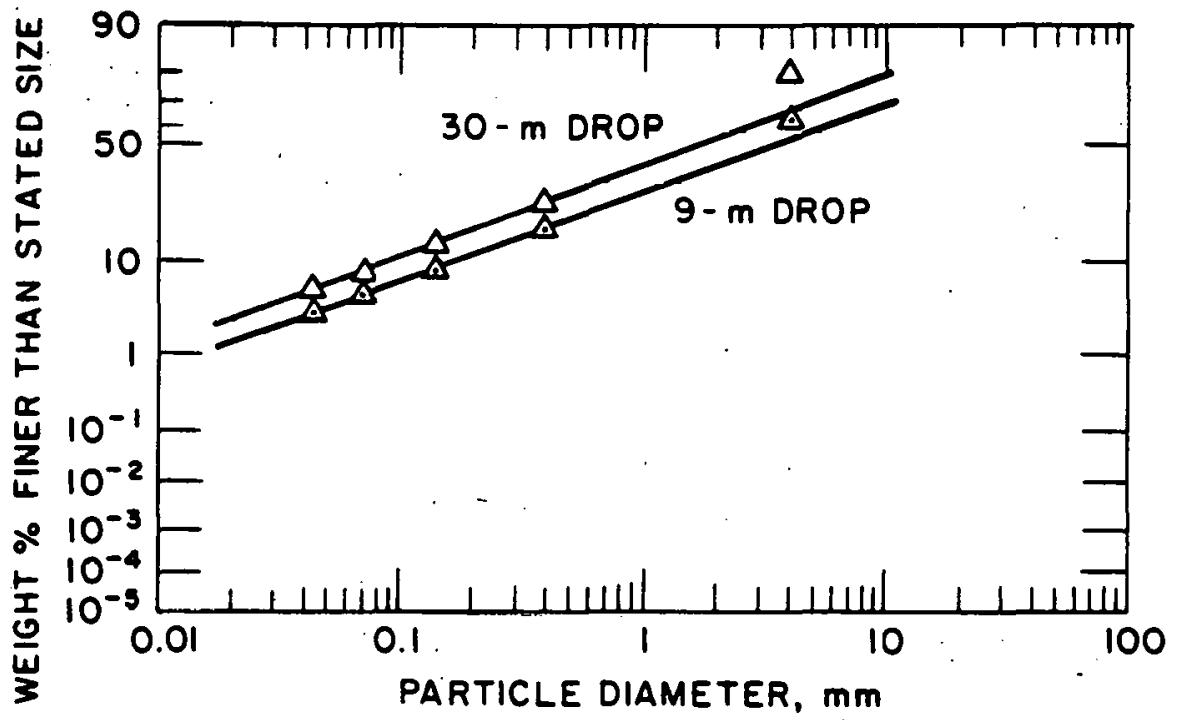

FIGURE 3. Particle Size Distributions for 9-Meter and 30-Meter Canister Impacts: Bottom Zone First $25 \mathrm{~mm}$ from Wall 
analysis can show two lognormal distributions: (1) the distribution for the fracture particulate proper, which contains most of the surface area and all of the respirable particles, and (2) a residual distribution of large fragments. The lognormal parameters of the fracture particulate proper correlate with the impact energy density, and the lognormal parameters of the residual distribution correlate with: (a) the original linear size of the original body which produced the fracture particulate proper and (b) the upper-limit size, $D_{98} \mathrm{~s}$, as defined above for the fracture particulate proper, on the basis of the fracture surface area. From conditions (a) and (b), lognormal parameters can be empirically defined for this second (residual) particulate population; however, there is usually no practical incentive to do so, since this distribution contains relatively little surface area and no respirable fines.

The reported total surface area for these full-scale impacts is low, relative to the gross input energy, in comparison to smal1-scale drop-weight tests of uncanistered glass specimens. This is not surprising, since the bending of the canister wall absorbs some of the impact energy. Moreover, these canistered waste forms were thermally fractured before impact, and in this condition the energy absorbed by the canister wall would be expected to be larger than the case in which the canistered glass were unfractured. If means are devised to reduce the amount of thermal fracture, it is possible that impact tests will show more extensive impact fracture of the waste glass than in the cases reported here.

The incentive for using lognormal analysis is that it yields parameters describing the particle size, and these parameters can be correlated with impact-severity parameters. These generalized correlations provide more understanding of the actual physical process involved than do uncorrelated data. These correlations also offer a basis for prediction of accident effects. From a research point of view, these correlations using lognormal parameters are an efficient use of experimental data, which is especially costly for full-scale impact tests of canistered waste glass.

A summary topical report is being drafted as an Argonne National Laboratory Report: Final Report of Experimental Laboratory-Scale Brittle Fracture Studies of Glasses or Ceramics. 
Activities of the Materials Characterization Center - MCC. The objective of the Materials Characterization Center (MCC) is to. ensure that qualified materials data are available on waste materials. This objective is to be met by 1) developing standard test methods, 2) testing waste materials by the standard methods, and 3) publishing the test methods and data, after review and approval by the Materials Review Board (MRB), in a Nuclear Waste Materials Handbook.

- Interactions with Materials Review Board (MRB)

A meeting with the MRB on October 6-10, resulted in provisional approval of MCC- 6 Method for Preparation and Characterization of Actinide-Doped Waste Forms and MCC-11 Splitting TensileStrength Test Method. Two other test methods, MCC-3 Agitated Powder Leach Test Method and MCC-103 Stress-Corrosion-Cracking Susceptibility Test Method, were reviewed by the Procedures Panel. Further revisions of both test methods were recommended.

A review of the MCC program was conducted October 5 by the MRB. The MRB members called for the MCC to issue a statement on precision and accuracy for eventual inclusion in the Nuclear Waste Materials Handbook.

- Standard Test Methods.

The MCC published two documents containing MCC standard test methods during the quarter. The Nuclear Waste Materials Handbook (DOE/TIC-11400) containing four MRB provisionally-approved methods, MCC-1, MCC-2, MCC-6, and MCC-11, was issued. A companion document, "Materials Characterization Center Test Methods Preliminary Version," PNL-3990, containing seven test methods that have been submitted to MRB, but not yet approved, was released with limited distribution.

Further inputs to MCC standard corrosion test methods were solicited from various NWTS programs including BWIP, NNWSI, Sandia, and PNL. The MCC prepared a plan for coordinating MCC submissions to the MRB with the various NWTS program and forwarded this plan to ONI.

- Testing

The analysis of data for the SRL comparative study on waste forms continued. Analyses of the data for five waste forms have been made for $\mathrm{Cs}, \mathrm{Sr}, \mathrm{U}, \mathrm{Ca}$, and $\mathrm{Si}$ leaching according to 
MCC-1' with deionized water at $90^{\circ} \mathrm{C}$. The relative ranking for the retention of uranium was, in order of increasing retention, SRL-131 glass, ORNL FUETAP concrete, Catholic University glass, Rockwell ceramic, and LLNL SYNROC (S29). The order of ranking was different for other elements. For example, for $\mathrm{Sr}$ the ranking was reversed except for ORNL FUETAP.

Experiments were initiated on the stability of the Teflon PFA leach container in gamma radiation. Results indicated that the Teflon can withstand $4.7 \times 10^{4} \mathrm{R}$ for air-saturated and argonpurged water at $90^{\circ} \mathrm{C}$. A dose of $7.8 \times 10^{6} \mathrm{R}$ produced discoloration and a more acid solution (lower $\mathrm{pH}$ ) than for the $4.7 \mathrm{x}$ $10^{4} \mathrm{R}$ dose. Experiments were also initiated to determine the suitability of fused quartz containers for leach tests on radioactive specimens.

Development of MCC-3 Agitated Power Leach Test Method continued with testing to determine particle size effects using Berghoff autoc laves.

An extensive test plan to characterize TMI Vitrified Zeolite with MCC test methods was completed. The testing to be done include static leach testing, thermal gas generation, splitting tensile strength impact testing, density, chemical analysis, and phase characterization. Specimen preparation was initiated and the static leach tests at $90^{\circ} \mathrm{C}$ for three, seven, fourteen, and twenty-eight days according to MCC-1P were started.

- Testing Equipment

The shielded ICP laboratury modification design was completed and the modifications were made.

Work was started on an automated ion-exchange instrument to facilitate leaching analytical work. The radiation corrosion test facility was completed and corrosion experiments conducted by the ONWI-funded Barrier Development Program were started.

A new high-temperature furnace was installed for MCC-6 specimen preparation and characterization.

- Leaching Mechanisms Program

A cooperative leaching mechanisms program, coordinated by the $\mathrm{MCC}$, was initiated at the beginning of the fiscal year. The goal of the program, which is scheduled to last three years, is to develop a defensible mathematical model that can be used to extrapolate leaching behavior of waste forms to long times in geologic repository fluids. 
Subcontracts were placed with all of the off-site participants in the leaching mechanisms program: the University of Florida, Catholic University of America, Pennsylvania State University, Rockwell Science Center, and Lawrence Livermore National Laboratory. Pacific. Northwest Laboratory is also a participant. In addition, the program will interact closely with leaching activities being conducted at SRL and the NWTS waste package programs. To further this interaction, a Leaching Mechanisms Workshop. was held in Seattle on October 27-28, 1981.

\section{Fixation of Waste in Glass}

The Porous Glass Matrix (PGM) Process for Fixation of Nuclear Wastes - CUA. The program has four major objectives: (1) optimization of the parameters of the PGM process including sludge processing, frit composition, crucible loading, percent waste loading and melt conditions; (2) production of samples containing composite, high $\mathrm{Al}_{2} \mathrm{O}_{3}$, and high $\mathrm{Fe}_{2} \mathrm{O}_{3}$ sludge for testing at CUA, SRL, and PNL; (3) initiation of leach tests of PGM and other candidate materials; (4) initiation of studies of the physical characteristics of PGM waste forms.

Results this quarter include: (1) the optimized process parameters; (2) leach test data on optimized PGM waste forms; and (3) preliminary observations of $P G M$ waste form microstructure.

Research for the next quarter will center around completing and analying the leach tests.

\section{- Parameter Optimization}

$\mathrm{High} \mathrm{Al}_{2} \mathrm{O}_{3}$, high $\mathrm{Fe}_{2} \mathrm{O}_{3}$, and composite sludges were received from SRI. All samples sent to SRL for testing contained SRL sludges. Additional samples containing composite sludge prepared at the Vitreous State Laboratory were sent to PNL. The sludge for these samples was prepared according to the procedures agreed upon previously by SRL and CUA but modified as follows: (1) batch size was cut by a factor of 20; (2) the sludge was dried on a hot plate with constant stirring;

(3) uranium was added to the dried sludge as $\mathrm{UO}_{2}\left(\mathrm{NO}_{3}\right)_{2} \cdot 6 \mathrm{H}_{2} \mathrm{O}$ powder. All sludges were vacuum dried at $350^{\circ} \mathrm{C}$, calcined for one hour at $850^{\circ} \mathrm{C}$ under vacuum, ball milled and sieved to -120 mesh size.

The final composition of the PGM frit that was mixed with the calcined sludge was as follows: 


\begin{tabular}{|c|c|c|c|}
\hline Oxide & Composite & $\begin{array}{l}\text { Weight } \% \\
\mathrm{High} \mathrm{Al}_{2} \mathrm{O}_{3} \\
\end{array}$ & $\mathrm{High} \mathrm{Fe}_{2} \mathrm{O}_{3}$ \\
\hline $\mathrm{SiO}_{2}$ & 81.0 & 88.1 & 71.8 \\
\hline $\mathrm{B}_{2} \mathrm{O}_{3}$ & 4.6 & 4.6 & 6.3 \\
\hline $\mathrm{Al}_{2} \mathrm{O}_{3}$ & 7.1 & & 13.3 \\
\hline $\mathrm{P}_{2} \mathrm{O}_{5}$ & 7.1 & 7.1 & 6.7 \\
\hline $\mathrm{ZrO}_{2}$ & & & 1.7 \\
\hline $\mathrm{Cs}_{2} \mathrm{O}$ & 0.21 & 0.21 & 0.20 \\
\hline
\end{tabular}

The Cs was ion exchanged onto porous glass which was then calcined to give a material which was $5 \% \mathrm{Cs}_{2} \mathrm{O}$. This material was then mixed with a suitably doped and calcined porous glass to give the final frit composition.

Each melt contained approximately $200 \mathrm{~g}$ of the waste/frit mixture in a lined, fused silica crucible of 2-in.-ID and 6-in. length. Graphite liners were used for the composite and high $\mathrm{Al}_{2} \mathrm{O}_{3}$ samples sent to -SRL. Tantalum liners were used for the high $\mathrm{Fe}_{2} \mathrm{O}_{3}$ samples sent to SRL and for the composite samples sent to PNL for leach tests. Owing to difficulties in obtaining tantalum foil, the final samples sent to PNL for mechanical and thermal tests were melted using graphite liners. Although the choice of liner seems to have little effect on leach rate, the tantalum reduces phase separation in the composite and high $\mathrm{Fe}_{2} \mathrm{O}_{3}$ samples. This may be due to the highly reducing nature of the graphite liner and its effect on the $\mathrm{Fe}^{+3} / \mathrm{Fe}^{+2}$ equilibrium. Prior to loading the crucible, waste and frit were blended for four minutes in a food blender.

The percent waste loadings after $\mathrm{Al}_{2} \mathrm{O}_{3}$ removal were $30 \%$ for composite waste, $30 \%$ for high-aluminum waste, and $25 \%$ for highiron waste.

Melting was carried out in a resistance heated vacuum ( $<300 \mu)$ furnace. The temperature program consisted of: (1) an 18-hour linear ramp from room temperature to the soak temperature; (2) four hours at the soak temperature; (3) a drop of $30^{\circ} \mathrm{C}$ and holding for one hour after admitting $\mathrm{N}_{2}$ gas; (4) cooling in the furnace. The furnace temperature was monitored by a thermocouple outside but near the heating coil. The indicated soak temperatures were $1190^{\circ} \mathrm{C}, 1200^{\circ} \mathrm{C}$, and $1210^{\circ} \mathrm{C}$ for the composite, high $\mathrm{Fe}_{2} \mathrm{O}_{3}$, and high $\mathrm{Al}_{2} \mathrm{O}_{3}$ samples, respectively. The temperatures of the samples were not determined directly during sintering but are known to be approximately $50^{\circ} \mathrm{C}$ higher than the indicated soak temperature. 
- Sample Production

During this report period a total of 15 PGM samples were prepared, 10 containing composite sludge, three containing high $\mathrm{Al}_{2} \mathrm{O}_{3}$ sludge, and two containing high $\mathrm{Fe}_{2} \mathrm{O}_{3}$ sludge. SRL received five of these samples (two composite, two high $\mathrm{Al}_{2} \mathrm{O}_{3}$, one high $\mathrm{Fe}_{2} \mathrm{O}_{3}$ ) and PNL received blocks cut from two composite samples. The remaining samples were held at CUA for use in leach testing and microstructure analysis.

\section{- Leach Testing}

Three types of leach tests were initiated during the program period. Frequent-exchange tests based on the IAEA specifications were carried out on all PGM samples as they were produced. These tests were completed during the program period and the results will be discussed below. IAEA tests were also initiated on SRL borosilicate glass, tailored ceramic and SYNROC. These tests will be completed during the next program period and the results given in the next quarterly report. Flow tests, designed to characterize the leach behavior of waste forms under a variety of flow/dilution conditions, and MCC tests were also initiated. These tests will also be completed and reported during the next program period.

Results of the IAEA tests of PGM samples conducted at $90^{\circ} \mathrm{C}$ can be found in Table 15 and Figures 4-7. By way of comparison, results for SRL borosilicate glass containing composite sludge with no uranium are also given in Table 15. The following results should be noted:

1. By the time the test has proceeded for 18 days, the leach rates have become fairly constant.

2. PGM waste glasses have leach rates 1-2 orders of magnitude lower than SRL waste glass.

3. Although the PGM-composite waste sample melted in the tantalum-lined crucible shows an initial matrix $\left(\mathrm{SiO}_{2}\right)$ dissolution rate that is below a similar sample melted in a graphite-lined crucible, the rates seem to be converging by the end of 18 days.

4. Although the PGM-high $\mathrm{Al}_{2} \mathrm{O}_{3}$ sample shows an initial dissolution rate that is less than the PGM-composite sample, the rates are almost identical after 40 days. 
5. The PGM-Fe sample has a leach rate that is superior to the other PGM samples. The superiority is most marked in the case of uranium where there was no detectable uranium release from the high $\mathrm{Fe}_{2} \mathrm{O}_{3}$ sample after 18 days. This sample is unique in having $\mathrm{ZrO}_{2}$ in the PGM frit. $\mathrm{ZrO}_{2}$ is known to increase glass durability.

\section{TABLE 15}

\section{Normalized Leach Rates: 18 Days at $90^{\circ} \mathrm{C}$}

\begin{tabular}{|c|c|c|c|c|c|c|}
\hline \multirow{2}{*}{ Sample } & \multirow{2}{*}{$\frac{\text { Leach }}{\mathrm{SiO}_{2}}$} & \multicolumn{2}{|c|}{ Rate $g /\left(\mathrm{m}^{2}\right)($ da $y)$} & \multirow{2}{*}{$\mathrm{Fe}$} & \multirow{2}{*}{$\mathrm{Sr}$} & \multirow{2}{*}{$\mathrm{U}$} \\
\hline & & 23 & & & & \\
\hline SRL & 1.2 & 1.0 & 1.3 & & 0.5 & \\
\hline$P G M-C-G$ & 0.12 & 0.24 & 0.10 & & 0.18 & 0.020 \\
\hline $\mathrm{PGM}-\mathrm{C}-\mathrm{Ta}$ & 0.06 & 0.12 & 0.10 & & 0.15 & \\
\hline PGM-Fe & 0.013 & 0.026 & 0.030 & 0.0035 & & $<0.002$ \\
\hline PGM-Al & 0.030 & 0.040 & 0.033 & & & 0.007 \\
\hline
\end{tabular}

Abbreviation:

SRL Savannah River Laboratory borosilicate glass containing composite sludge but no uranium

PGM-C-G PGM-composite waste sample melted in a graphite-lined crucible

PGM-C-Ta PGM-composite waste sample melted in a tantalum-lined crucible

PGM-Fe PGM-high $\mathrm{Fe}_{2} \mathrm{O}_{3}$ waste sample

PGM-Al PGM-high $\mathrm{Al}_{2} \mathrm{O}_{3}$ waste sample

- Physical Characterization

Preliminary observations made using electron microscopy indicate that the PGM waste forms consist of crystalline phases isolated in an interconnected phase. The latter phase appears to be a high-silica glass accounting for the high overall durability of the waste forms. The uranium in the high $\mathrm{Fe}_{2} \mathrm{O}_{3}$ waste form seems to be concentrated in a crystalline phase that is also high in zirconium. This may account for the low uranium leach rate of this form. Additional electron microscopy studies will be carried out during the next report period. 


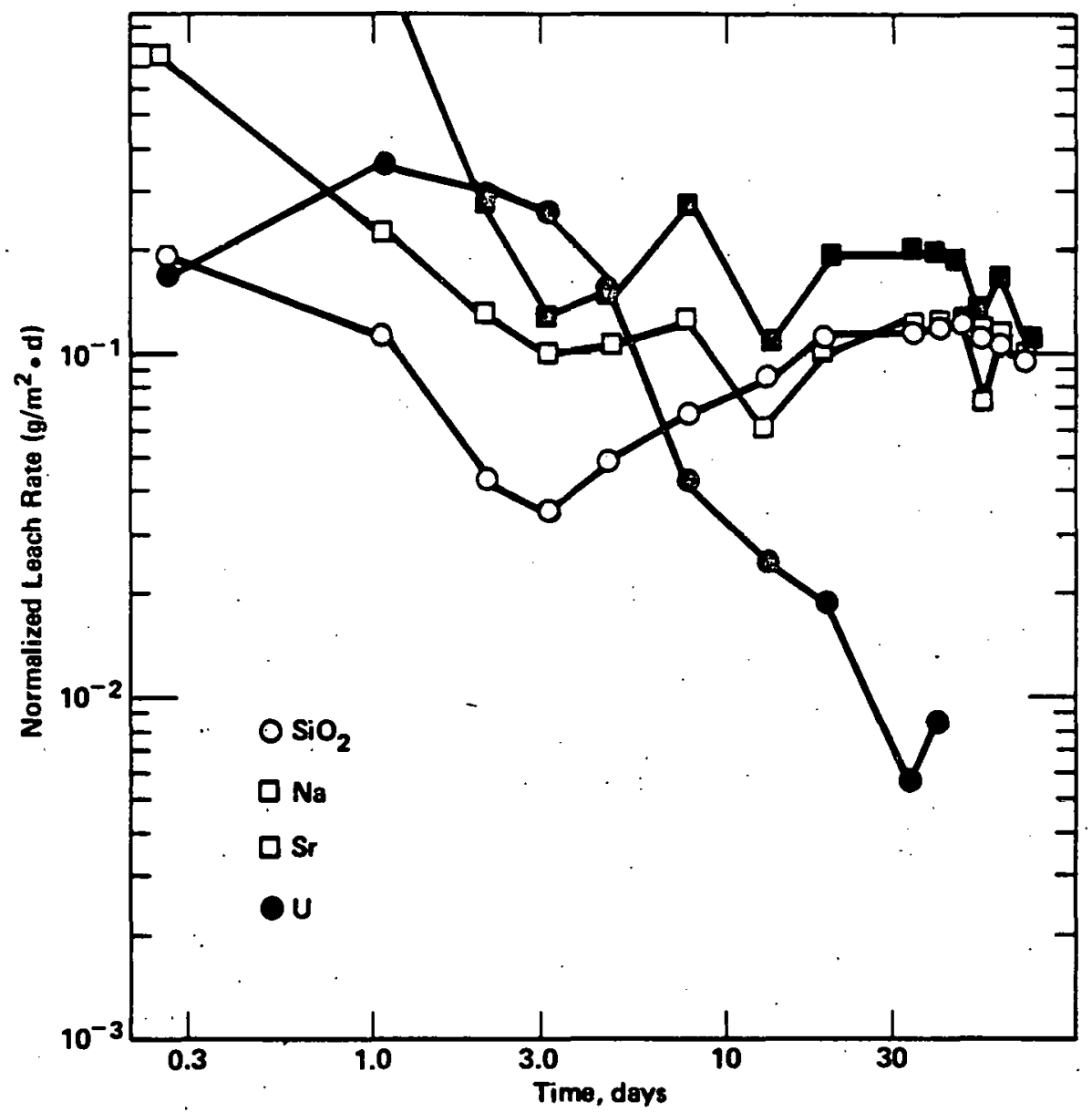

FIGURE 4. Porous Glass Matrix - Composite Graphite Liner 


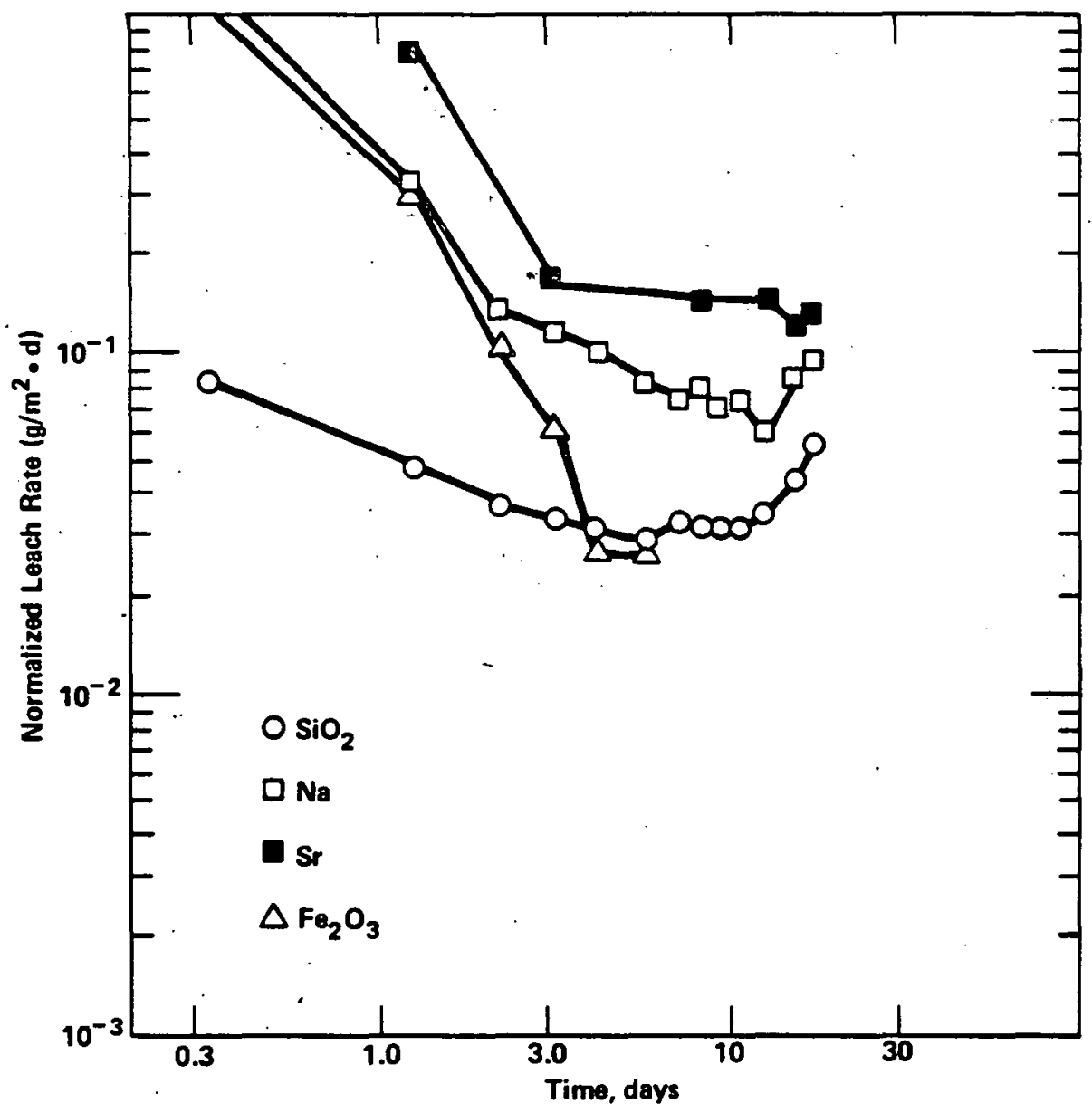

FIGURE 5. Porous Glass Matrix - Composite Tantalum Liner 


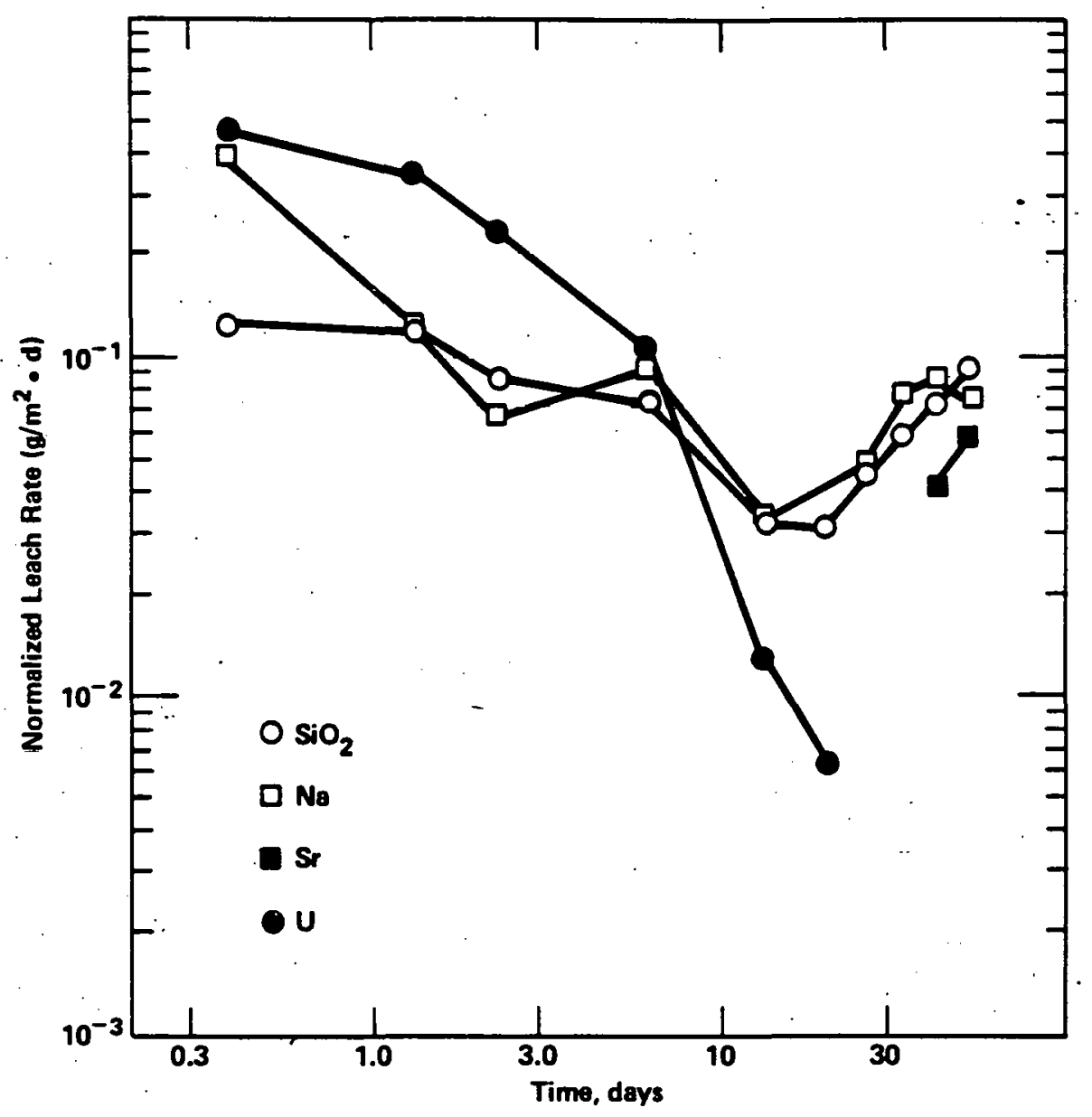

FIGORE 6. Porous Glass Matrix - High Aluminum 


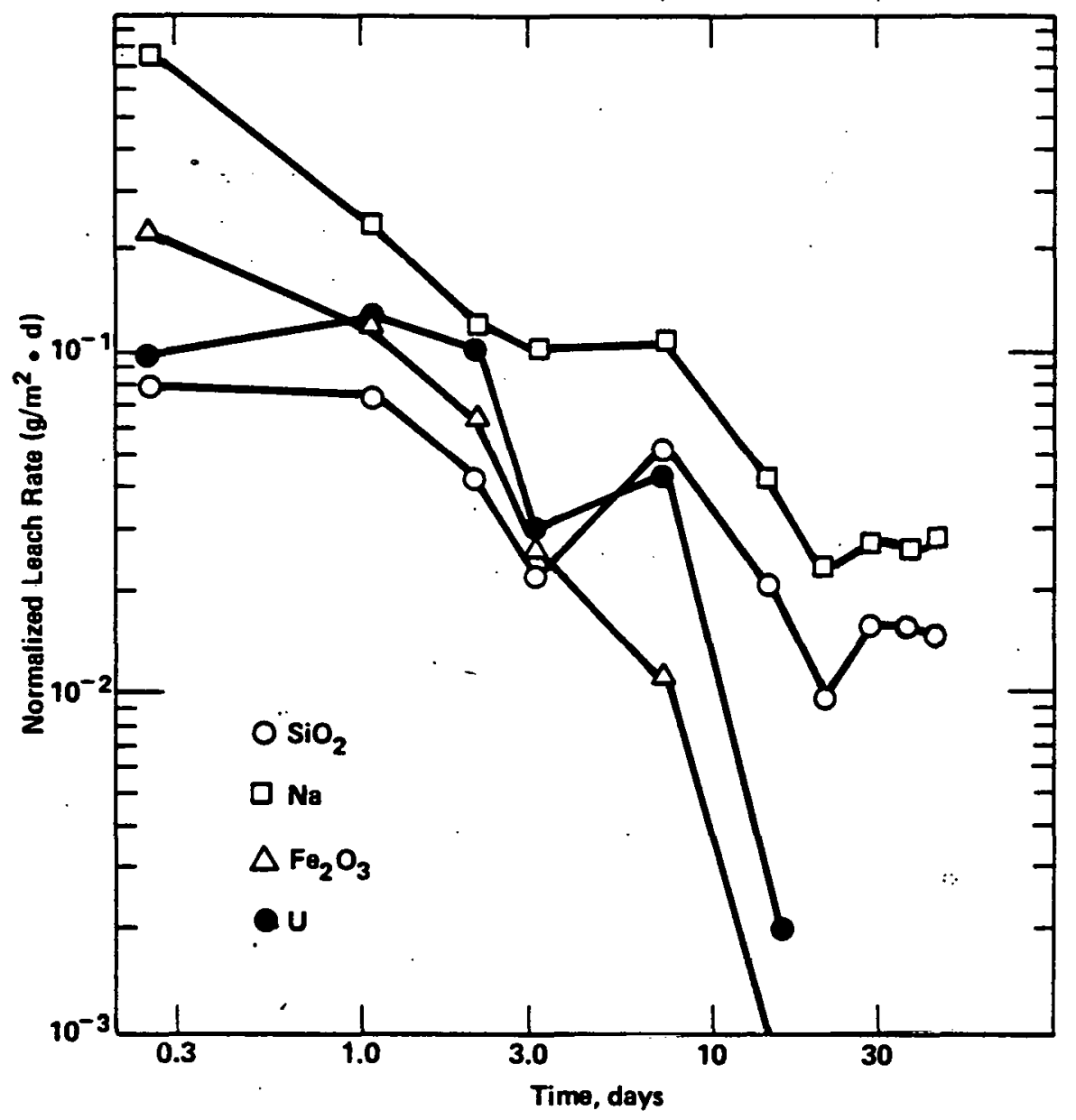

FIGURE 7. Porous Glass Matrix - High Iron 
Durability of SRP Waste Glass-Effects of Waste Loading - SRL. Borosilicate glass is the reference form for long term storage of SRP high-level radioactive waste. In the current reference process, approximately 28 wt \% waste oxides ( 35 wt \% alkaline waste) is incorporated into the glassy matrix. The objective of the present study is to better define the optimum waste loading in the glass, and to determine if higher waste loadings are feasible. If they are, less waste glass would be produced, and significant cost savings would be realized.

The single most important property associated with SRP waste glass is its leachability. Therefore, the leachability was evaluated as a function of waste loading varying from 0 to 50 wt $\%$ oxides. Leachability experiments were performed using modified MCC-1 standard leach tests with ultra-pure water and specially prepared buffered solutions as leachants. In addition, scouting tests were performed on key processing parameters (viscosity and electrical resistivity). Based on these data, we conclude the following:

- The durability of the waste glass improves due to the presence of the waste, for waste oxide loadings up to 50 wt \%.

- Data indicate that the practical limit of waste loading will not be restricted by chemical durability but by processing considerations. Significant cost savings in the overall waste disposal system would result if the waste loading is increased above the reference 28 wt \% oxides.

- The viscosity of waste glass melts is minimized between 20 and 37 wt \% waste oxides. However, even a 50 wt \% waste oxide melt could be processed at $1150^{\circ} \mathrm{C}$, based on small-scale tests.

- Key processing parameters such as viscosity and electrical resistivity are not significantly changed for a waste loading of 35 wt \% oxides ( $25 \%$ increase over the reference process), while durability improves by $30 \%$ (based on mass loss).

\section{Fixation of Waste in Concrete}

Characterization of FUETAP Concrete - ORNL. Since the closeout report is scheduled to be prepared in the second and third quarters of FY-82, a reduced level of activity was directed at completion, analysis, and clean-up of leach experiments which were begun in $\mathrm{FY}-81$. 
These leach experiments were aimed at controlling and characterizing the cesium leaching from the zeolite used in the proposed FUETAP flowsheet for the comparison with the SRP Reference Glass plant. The results will be collated and reported in the final close-out report.

\section{Fixation of Waste in Tailored Ceramics}

Ceramic Formulations for SRP High-Level Waste - RES. The formulations currently under study at Rockwell International for producing a polyphase ceramic form from simulated SRP waste are shown in Table 16. LLNL S29 formulation shown is the reference SYNROC $D$ published by the Lawrence Livermore National Laboratory (LLNL), while the LS04HP4A formulation describes the optimized LLNL form. The four RSC-S29 descriptions are Rockwel1-formulated variations of 529 intended to investigate the effects of various cations, anions, and redox control states upon the final ceramic. RSC-S29-1 contains those extra cations and anions described by SRL as being present in SRP waste, RSC-S29-2 and RSC-S29-4, are essentially identical repeat runs without the added cations, while RSC-S29-3 simulates the original LLNL S29 without added cations or $\mathrm{PO}_{4}{ }^{3-}$.

- Phase Content of Modified S29 Ceramic

The basic RSC-S29 processing approach has been to apply only that redox control necessary to reduce the uranium in the waste to the $\mathrm{U}^{4+}$ state in the consolidated ceramic. This provides a greater quantity of trivalent $F e$ in the ceramic to furlu ing new toplumbite as a $C_{s}$ and $S r$ host phase than is present in the more extensively reduced LLNL 529 or LS04HP4A formulations. has been shown that simply by heating the tailored waste powders in argon at temperatures between 800 and $1000^{\circ} \mathrm{C}$, the desired redox control can be obtained.

The resulting ceramic formed by HIPping at $1040^{\circ} \mathrm{C}$ of the RSC-S29 formulation has a density of 3.96 to $4.06 \mathrm{~g} / \mathrm{cm}^{3}$. In Table 17, the phase content and elemental distribution (as found by XRD and STEM analysis) of the RSC-S29 is compared to that found in the LLNL LS04HP4A.

The addition of trace-level cations in RSC-S29-1 had the effect of increasing the volume content of the magnetoplumbite phase, at the expense of the spinel, pseudobrookite, and hematite. The flexible MP structure readily accepts $\mathrm{Ba}, \mathrm{Pb}, \mathrm{La}, \mathrm{Cr}$, Co, $\mathrm{Zn}, \mathrm{Mg}$, etc.; hence, these cations pose no significant problem in the waste form assemblage. 
TABLE 16

Waste Form Compositions Currently Under Study

\begin{tabular}{|c|c|c|c|c|c|c|}
\hline $\begin{array}{l}\text { Component } \\
\text { Oxide } \\
\end{array}$ & $\begin{array}{l}\text { LS-29 } \\
\text { wt \% }\end{array}$ & $\begin{array}{c}\mathrm{LSO} 4 \mathrm{HP} 4 \mathrm{~A} \\
\text { wt } \% \\
\end{array}$ & $\begin{array}{l}\text { RSC-S29-1 } \\
\text { wt \% } \\
\end{array}$ & $\begin{array}{c}\text { RSC-S29-2 } \\
\text { wt } \% \\
\end{array}$ & $\begin{array}{c}\text { RSC S29-3 } \\
\text { wt \% } \\
\end{array}$ & $\begin{array}{c}\text { RSC S29-4 } \\
\text { wt \% } \\
\end{array}$ \\
\hline $\mathrm{Fe}_{2} \mathrm{O}_{3}$ & 23.80 & 23.26 & 18.23 & 18.06 & 23.80 & 18.06 \\
\hline $\mathrm{MnO}_{2}$ & 7.40 & 6.57 & 4.36 & 4.09 & 7.40 & 4.09 \\
\hline $\mathrm{Al}_{2} \mathrm{O}_{3}$ & 18.60 & 18.52 & 19.11 & 17.76 & 18.60 & 17.76 \\
\hline $\mathrm{CaO}$ & 7.10 & 6.97 & 8.25 & 8.49 & 7.10 & 8.49 \\
\hline $\mathrm{NiO}$ & 3.00 & 2.57 & 1.97 & 1.52 & 3.00 & 1.52 \\
\hline $\mathrm{SiO}_{2}$ & 7.20 & 7.16 & 8.27 & 9.92 & 7.20 & 9.92 \\
\hline $\mathrm{U}_{3} \mathrm{O}_{8}$ & 2.10 & 2.14 & 2.49 & 2.49 & 2.10 & 2.49 \\
\hline $\mathrm{Na}_{2} \mathrm{O}$ & 3.30 & 3.33 & 3.32 & 4.43 & 3.30 & 4.43 \\
\hline $\mathrm{ThO}_{2}$ & - & - & 0.46 & 0.46 & - & 0.46 \\
\hline $\mathrm{Ce}_{2} \mathrm{O}_{3}$ & 0.50 & 0.52 & 0.38 & 0.38 & 0.50 & 0.38 \\
\hline $\mathrm{ZrO}_{2}$ & 6.60 & 6.28 & 7.91 & 7.89 & 6.60 & 7.89 \\
\hline $\mathrm{Cs}_{2} \mathrm{O}$ & 0.25 & 0.26 & 0.22 & 0.20 & 0.25 & 0.20 \\
\hline Sro & 0.25 & 0.26 & 0.30 & 0.22 & 0.25 & 0.22 \\
\hline $\mathrm{BaO}$ & - & - & 0.13 & - & - & - \\
\hline $\mathrm{PbO}$ & - & - & 0.08 & - & - & - \\
\hline $\mathrm{La}_{2} \mathrm{O}_{3}$ & - & - & 0.09 & 0.34 & - & 0.34 \\
\hline $\mathrm{Cr}_{2} \mathrm{O}_{3}$ & - & - & 0.22 & - & - & - \\
\hline CuO & - & - & 0.07 & - & - & - \\
\hline $\mathrm{CoO}$ & - & - & 0.04 & - & - & - \\
\hline $\mathrm{PrO}_{2}$ & - & - & 0.08 & - & - & - \\
\hline Zno & - & - & 0.18 & - & - & - \\
\hline MgO & - & - & 0.28 & - & - & - \\
\hline $\mathrm{TiO}_{2}$ & 18.80 & 20.53 & 22.51 & 22.48 & 18.80 & 22.48 \\
\hline $\mathrm{Na}_{2} \mathrm{SO}_{4}$ & 0.60 & 0.69 & 0.57 & 0.57 & 0.60 & 0.57 \\
\hline $\mathrm{Na}_{3} \mathrm{PO}_{4}$ & - & - & 0.63 & 0.70 & - & 0.70 \\
\hline $\mathrm{Nd}_{2} \mathrm{O}_{3}$ & $\frac{0.50}{100.00}$ & $\frac{-}{100.00}$ & $\frac{-}{100.00}$ & $\frac{-}{100.00}$ & $\frac{0.50}{100.00}$ & $\frac{-}{100.00}$ \\
\hline$\%$ Waste & $62.7^{\circ}$ & - & 61.7 & 59.8 & 62.7 & 59.8 \\
\hline
\end{tabular}




\section{TABLE 17}

Phase Content and Elemental Distribution in the RSC-S29 and LLNL LS04HP4A Ceramics as Determined by XRD and STEM Analysis

RSC-S29 Phases

Nepheline

Spinel (magnetite-type)

Magnetoplumbite

Zirconolite

Perovskite (minor phase)

New cubic phase

Amorphous phase

Hematite (trace)

Pseudobrookite (trace)

Trace unknown

\section{LS04HP4A Phases}

Nepheline + glass

Spinel 1 (hercynite-type)

Spinel 2 (ulvo-type)

Zirconolite

Perovskite.

New cubic (trace)

$\gamma$-iron alloy

$\alpha$-iron alloy

Trace unknowns
Elemental Content*

$\mathrm{Si}, \mathrm{Al}, \mathrm{Na}, \mathrm{Ca}, \mathrm{Fe}, \mathrm{Ti}, \mathrm{Cs}$

$\mathrm{Fe}, \mathrm{Ti}, \mathrm{Mn}, \mathrm{Al}, \mathrm{Ni}$

$\mathrm{Fe}, \mathrm{Al}, \mathrm{Ti}, \mathrm{Mn}, \mathrm{Ca}, \mathrm{Si}, \mathrm{Na}, \mathrm{Ni}, \mathrm{Sr}$

$\mathrm{Zr}, \mathrm{Ti}, \mathrm{Ca}, \mathrm{U}, \mathrm{Fe}, \mathrm{Mn}, \mathrm{Al}$

Not found by STEM

$\mathrm{Zr}, \mathrm{Ti}, \mathrm{Fe}, \mathrm{Al}, \mathrm{Ca}, \mathrm{Mn}, \mathrm{U}$

$\mathrm{Si}, \mathrm{Al}, \mathrm{Ca}, \mathrm{Fe}, \mathrm{Ti}, \mathrm{Na}$

\section{Elemental Content*}

$\mathrm{Al}, \mathrm{Si}, \mathrm{Fe}, \mathrm{Ti}, \mathrm{Ca}, \mathrm{Na}, \mathrm{Mn}, \mathrm{Zr}$

-Al, $\mathrm{Fe}, \mathrm{Mn}, \mathrm{Ti}$, trace $\mathrm{Ni}, \mathrm{Ca}, \mathrm{Zr}$

$\mathrm{Fe}, \mathrm{Ti}, \mathrm{Mn}, \mathrm{Al}, \mathrm{Ca}$, trace $\mathrm{Ni}, \mathrm{Zr}$

$\mathrm{Zr}, \mathrm{Ti}, \mathrm{Ca}, \mathrm{Fe}, \mathrm{Mn}, \mathrm{U}, \mathrm{trace} \mathrm{Al}, \mathrm{Si}$

$\mathrm{Ti}, \mathrm{Ca}, \mathrm{U}, \mathrm{Zr}, \mathrm{Sr}, \mathrm{Na}, \mathrm{Al}, \mathrm{Ce}$, trace Nd

$\mathrm{Zr}, \mathrm{Ti}, \mathrm{Fe}, \mathrm{Al}, \mathrm{Ca}, \mathrm{Mn}, \mathrm{U}$

* In order of concentration as determined by STEM

Note: Cs was not observable by STEM in the LS04HP4A; Sr was observed in the localized areas of glass phase. 
The anions $\mathrm{Cl}^{1-}$ and $\mathrm{SO}_{4}{ }^{2-}$ prefer to form hauynite in the ceramic if not removed by the reduction steps. The poor leach resistance of the hauynite for $\mathrm{Na}$ does require that the anions be volatilized during reduction, an operation which poses no problems in processing. The $\mathrm{PO}_{4}{ }^{3-}$ anions were not identified in the ceramic form; however, it is expected that they enter the amorphous phase and may contribute to increased stability of the phase.

- Conditions For Hot Isostatic Pressing (HIP)

Variation of the HIP pressures and temperatures has shown that full consolidation can be obtained at pressures in excess of 7000 psi at temperatures over $1000^{\circ} \mathrm{C}$. Table 18 shows the observed density of the ceramic forms as a function of HIP pressure, starting with several green densities. 'The low pressures required to reach full density indicate that significant safety and economic benefits can be obtained by running remote HIPping below 10,000 psi. The low green density at which full final density can be obtained could greatly simplify the preconsolidation step.

Temperature variation studies have confirmed that consolidation temperatures above $1000^{\circ} \mathrm{C}$ improve crystallinity while temperatures above $1100^{\circ} \mathrm{C}$ increase the amorphous phase. Hence, 1040$1060^{\circ} \mathrm{C}$ was selected as the optimum range for this laboratory study.

\section{- Redox Control}

Three types of redox control have been investigated including heating in argon, the use of monoethanolamine (MEA), and comparison against LLNL $\mathrm{CO} / \mathrm{CO}_{2}$-buffered ceramics. The results of the experiments show that the ceramic form is extremely flexible with respect to redox control.

Redox studies in argon at temperatures of 700 to $1000^{\circ} \mathrm{C}$ showed the expected trend towards increasing reduction of the waste powders with temperature. Increasing the reduction lowered the amount of pseudobrookite and $\mathrm{Fe}_{2} \mathrm{O}_{3}$ observed in the ceramic and, at temperatures greater than $900^{\circ} \mathrm{C}$, no hauynite was observed, iudicating the volatilisation of all $\mathrm{SO}_{4}{ }^{2-}$ and $\mathrm{Cl}^{1-}$. At all temperatures above $700^{\circ} \mathrm{C}$, the desired magnetoplumbite phase formed and uranium was predominantly $\mathrm{II}^{4+}$. 
TABLE 18

Final Density of RSC-S29 Ceramics as a Function of HIP Pressure at $1040^{\circ} \mathrm{C}$

\begin{tabular}{cccc}
$\begin{array}{c}\text { Pressure } \\
(\mathrm{ksi})\end{array}$ & $\begin{array}{c}\text { Green } \\
\text { Density } \\
\left(\mathrm{g} / \mathrm{cm}^{3}\right.\end{array}$ & $\begin{array}{l}\text { Density } \\
\left(\mathrm{g} / \mathrm{cm}^{3}\right)\end{array}$ \\
\cline { 1 - 1 } 4 & & 1.85 & 3.69 \\
7 & 1.85 & 3.95 \\
10 & 0.85 & 3.95 \\
10 & 1.31 & 3.97 \\
14 & 1.85 & 3.97 \\
21 & 1.85 & 3.97 \\
28 & 1.85 & 3.97
\end{tabular}


The MEA studies showed that the MEA produces equivalent redox control to the gas techniques. Approximately 4 wt \% MEA in the waste, with drying to $300^{\circ} \mathrm{C}$ and subsequent heating in argon to $800^{\circ} \mathrm{C}$, produces the same state of reduction as the $\mathrm{LLNL} \mathrm{CO} / \mathrm{CO}_{2}$ buffer.

The redox control studies demonstrate that in a production situation, the desired redox states can be obtained by a variety of methods. The studies also confirm the flexibility which is available in processing, as all the ceramics produced showed superior leach resistance and acceptable phase assemblages.

\section{- Comparative Leach Studies}

The comparative leach test data shown in Table 19 confirm four basic results:

1. Both the optimized LLNL LS04HP4A and the Rockwel.1 RSC-S29 forms are significantly better than the original LLNL S29 reference form for $\mathrm{Sr}$ retention.

2. The RSC-\$29 forms offer a factor of 2 to 4 improvement over the more reduced forms in $\mathrm{Cs}$ retention.

3. The presence of $\mathrm{PO}_{4}^{3-}$ in $\mathrm{RSC}-\mathrm{S} 29-1,-2$, and -4 did not lower the forms' leach resistance, indicating either that the phosphate is effectively bound in the ceramic or that the redox control steps volatilize the anion.

4. All the forms tested offer superior leach resistance, demonstrating the broad range of processing conditions, anion and cation content which can be effectively handled by the ceramic form and processing.

In general, these data support the RSC-S29/LS04HP4A formulations as providing a very flexible ceramic form for defense waste. The processing is forgiving to both redox control and consolidation conditions. The leach performance and mechanical properties of the form are, to a great extent, controlled by the amorphous phase which does not host either uranium or the rare earths. Further improvements in the form can be obtained by optimizing the magnetoplumbite phase as a Cs host and by minimizing the amount of intergranular phase present. Work is continuing on defining the anion effects, compositional flexibility, and optimum processing conditions for the form. Threemonth leach testing experiments on RSC-S29 composition ceramics are underway. 
TABLE 19

Summary of Comparative Leach Data

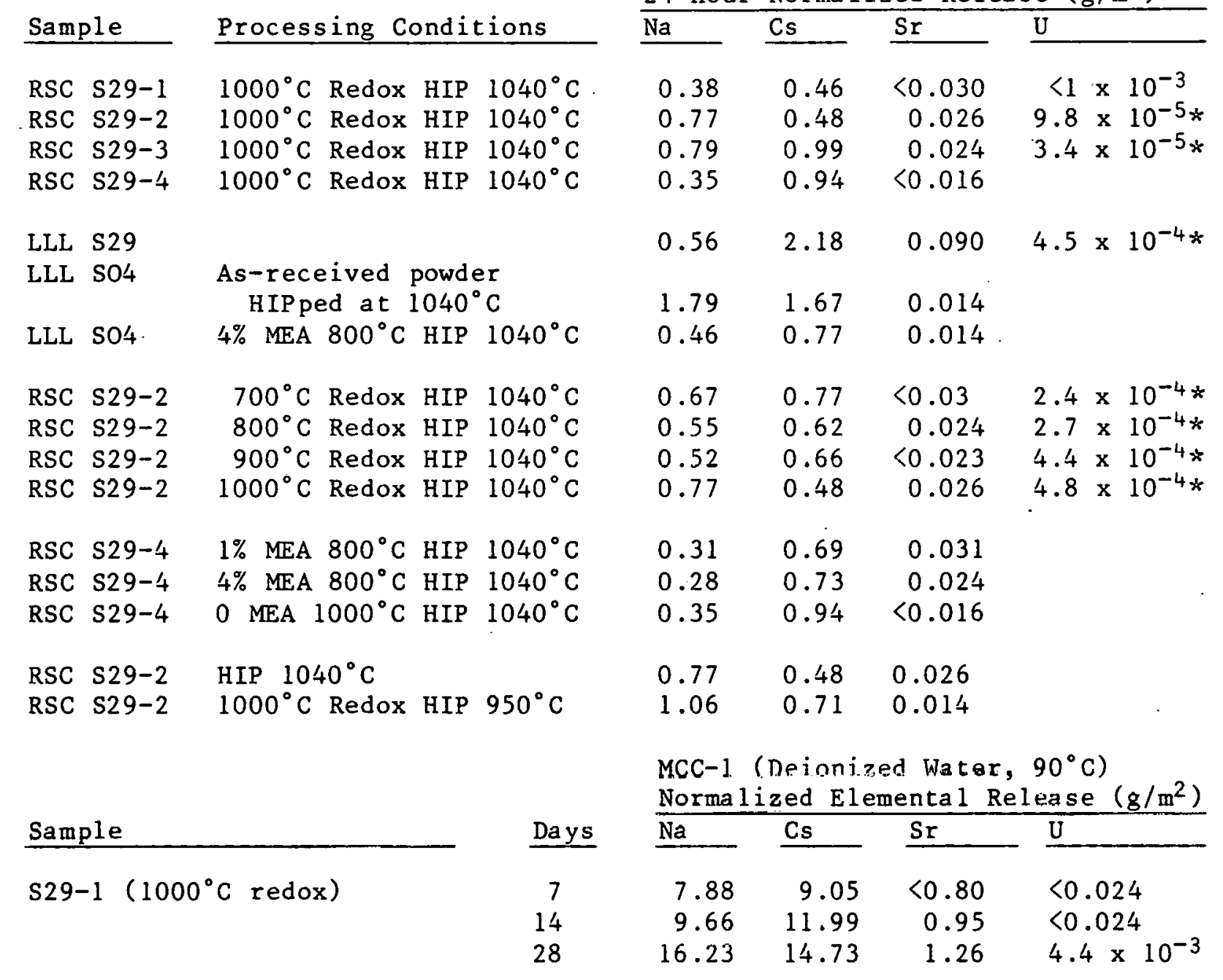

MCC-3 (Deionized Water, $150^{\circ} \mathrm{C}$ )

24-Hour Normalized Release $\left(\mathrm{g} / \mathrm{m}^{2}\right)$

(28 day analysis by LLNL)

* Second day leach, 24-hour test 
Development of Crystalline Ceramic Waste Forms - Final Report - ANL. The goals of the Argonne portion of the SYNROC Program were achieved during FY 1981. A final report to document the experimental work and results is in preparation. The report is in two parts covering fabrication and characterization. The part on fabrication includes (1) the effects of oxygen partial pressure, (2) production rate of fabrication by extrusion, and (3) single phase fabrication. The part of the report on characterization includes (1). phase equilibra as a function of oxygen partial pressure for three-phase SYNROC and the stoichiometry of the $\mathrm{Ba}-$ hollandite phase; (2) leach resistance measured for times as long as 28 days at temperatures of $40^{\circ} \mathrm{C}, 90^{\circ} \mathrm{C}$, and $200^{\circ} \mathrm{C}$; (3) mechanical properties including impact resistance, elastic modulus and tensile properties; (4) radiation damage with $3.5-\mathrm{MeV}$ helium ions, 250 and 300-keV Krypton ions, and 300-keV helium ions; (5) effect of radiation damage on leach resistance; and (6) leach resistance and the effect of radiation damage on leaching properties for selected glass compositions as a comparison with SYNROC results.

\section{Coated Waste Forms}

Sol-Gel Coated Particles - ORNL. During this quarter, leach testing of coated and uncoated waste forms was performed. Both the MCC-1 and MCC-2 tests were utilized.

Samples of pyrocarbon-coated SYNROC D were leach tested for 28 days according to MCC-1 procedures in deionized water, silicated water, and brine. Additional MCC-2 leach tests were performed on pyrocarbon-coated SYNROC $D$ in silicate water and brine. No $\mathrm{Fe}, \mathrm{Al}, \mathrm{Mn}, \mathrm{U}, \mathrm{Ca}, \mathrm{Si}, \mathrm{Nd}$, or $\mathrm{Sr}$ were detected in the leach solutions for any of the five tests. The detection limits for these elements were typically between $1 \times 10^{-5}$ and $5 \times 10^{-4}$ $\mathrm{g} / \mathrm{m}^{2} \cdot \mathrm{d}$. These data are many orders of magnitude less than the data measured on uncoated SYNROC D.

Samples of pyrocarbon-coated cesiumi-loaded zeulile wére leached according to MCC-1 procedures in deionized water, silicated water, and brine. No cesium was detected in any of these solutions which indicated that the leach rate was less than $5 \times 10^{-6} \mathrm{~g} / \mathrm{m}^{2} \cdot \mathrm{d}$. MCC-2 leach tests were performed in deionized water, silicated water, and brine. These tests determined that the leach rate for cesium was approximately $4 \times 10^{-5} \mathrm{~g} / \mathrm{m}^{2} \cdot \mathrm{d}$. Uncoated zeolite (heat treated at $600^{\circ} \mathrm{C}$ in air) was leached in deionized water according to MCC-1 procedures and found to lose cesium at a rate of $1 \times 10^{-2} \mathrm{~g} / \mathrm{m}^{2} \cdot \mathrm{d}$; the aluminum and silicon leached more slowly $\left(\sim 5 \times 10^{-3} \mathrm{~g} / \mathrm{m}^{2} \cdot \mathrm{d}\right)$. 
Samples of $90 / 10$ and cesium-loaded zeolite coated with SiC and over-coated with $\mathrm{PyC}$ were leach tested in deionized water at $90^{\circ} \mathrm{C}$ using the MCC-1 procedure. The leach tests have been completed, and the solutions are being analyzed. The coatings on the particles were applied with all gas concentrations under the explosive limit if mixed with air. The process by which they were coated was similar to the reference process proposed by ORNL for solidification of SRP waste.

Additional Sic coating development was performed to determine the influence of additive and fluidizing gas concentration on the stoichiometry and physical characteristics of the coatings. Argon and nitrogen were used as the fluidization gases. The coatings appeared to be similar irrespective of the type of fluidizing gas. Small amounts of hydrocarbon gas have been added to the SiC coating process. Experimental observation of the coatings by the Raman technique have confirmed the calculated stoichiometry data. Stoichiometric SiC can now be produced either in an argon or $\mathrm{H}_{2}$ fluidizing atmosphere.

The feasibility of coating processed defense waste calcine (Idaho aluminum and zirconium calcine) was shown. The calcined particles were coated with PyC at $1000^{\circ} \mathrm{C}$. Optical microscopy revealed no reactions between the pyrocarbon and the kernels.

A report entitled "Coating Crystalline Nuclear Waste Forms to. Improve Inertness" authored by D. P. Stinton, P. Angelini, A. J. Caputo, and W. J. Lackey was submitted for publication to the American Ceramic Society.

A summary project report consisting of gelation, drying and sintering, and coating development is being prepared.

Process and Equipment Development (1.3.2)

SYNROC D Reference Process - LLNL. During FY 1981, a preliminary SYNROC reference process was developed based on laboratory preparation steps used to produce our first SYNROC samples. The reference process was used by SRL to develop a preliminary engineering layout of the process cell. The process is shown in schematic form in Figure 8 . The washed sludge and $\mathrm{Cs} / \mathrm{Sr}$ separated from the supernate are mixed with SYNROC additives and ball milled to particle sizes of $<10 \mu \mathrm{m}$. The resultant slurry is spray calcined at a temperature between $650^{\circ} \mathrm{C}$ (minimum for $99 \%$ decomposition) and $800^{\circ} \mathrm{C}$ (maximum to prevent significant mineralization). The spray calcined powder is blended with a metal powder ( $\mathrm{Ni}, \mathrm{Fe}$ or $\mathrm{Ti}$ ) for in situ redox control and the mixture loaded and sealed in large containers for hot isostatic pressing (HIP). The HIP unit is a large 5-ft. x 5-ft.-diameter vessel where the sealed 


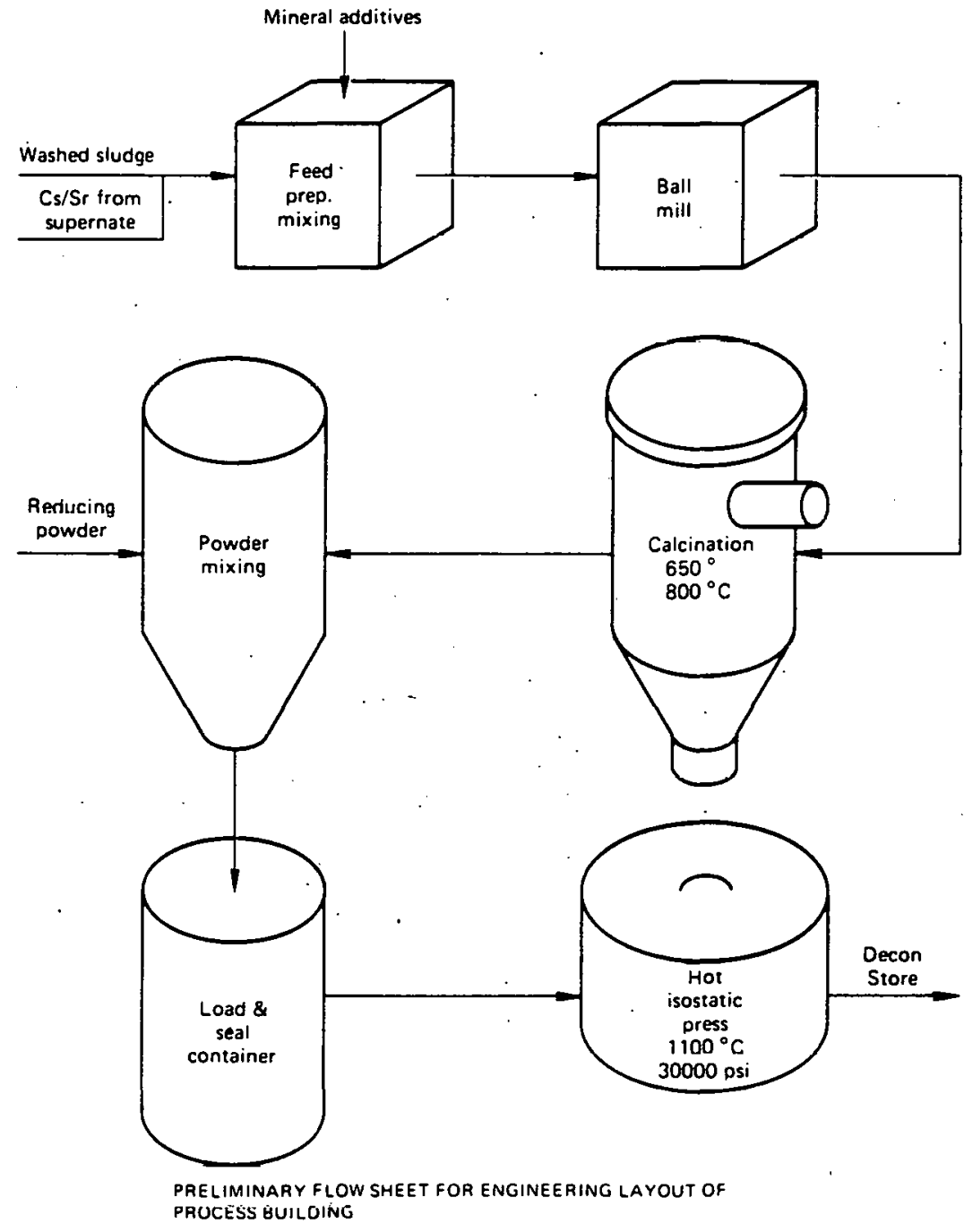

FIGURE 8. Preliminary Flow Sheet for Engineering Layout of Process Cell 
containers are subjected to high temperature $\left(1000-1100^{\circ} \mathrm{C}\right)$ and pressure $(15,000$ psi) to produce a monolith of greater than $92 \%$ theoretical density. Since the time this preliminary engineering layout was developed, significant advances have been made in the SYNROC process technology. In the next several sections, these developments are highlighted.

Reduction of Processing Cell Area

Based upon the first laboratory preparation procedure; the initial processing flowsheet and plant layout included a ball milling operation. 6 For redundancy, two hot isostatic units (HIP) each with complete support facilities were also included. After critically reviewing the particle size requirements and HIP size/cycle time relationships (see following sections), we conclude that the ball milling operation and one HIP unit may be eliminated. The effect of this on processing area requirements is to reduce the initial layout length from 390 feet to 270 feet. Other areas of possible reduction involve consolidation of the two separate off-gas scrubber tank systems for the calciner and canister preheat into one system and replacement of the metal powder redox control step by a gas phase redox method. This gas phase method could be done in conjunction with the spray calciner operation and would eliminate the powder blending operation. Replacement of the spray calciner with a more compact fluidized bed unit is also under study. This should result in additional simplifications in the flowsheet and allow cost savings in plant layout.

\section{- Powder Processing}

Measurements of particle size distribution on samples from waste storage tanks show that a large fraction are $<20 \mu \mathrm{m}$. The particles $>20 \mu \mathrm{m}$ are mostly inert sand or similar components. One operating scenario is to screen these out (including the grit blast material) and handle as a separate low level waste stream. Another possibility is to separately add them back in the spray calciner through a large orifice spray. nozzle. Intimate mixing of these relatively inert particles with a main stream is not required since final product performance is unaffected by the presence of a few inert unreacted particles $\left(\mathrm{TiO}_{2}, \mathrm{Al}_{2} \mathrm{O}_{3}, \mathrm{SiO}_{2}\right.$, etc.). Our laboratory preparations are presently done routinely without a grinding operation and produce a good product as long as the main SYNROC additives are well mixed with the radwaste components. Furthermore, the particle size distribution of the powders we are currently spray drying and hot pressing is greater than that reported for the SRP waste sludge. Consequently, ball-mill reduction of the sludge particle size is not required for the current SYNROC process. 
The reference SYNROC flowsheet calls for in situ redox control using metal powders. However, our present laboratory redox control is by gas phase reaction using a $1 / 10 \mathrm{CO} / \mathrm{CO}_{2}$ gas mixture. Reaction kinetics are very fast at temperatures of $350^{\circ} \mathrm{C}$ or higher (Figure 9) and the $1 / 10$ mixture is below the combustion limit. Reaction with the calcined powders further reduces the $\mathrm{CO}$ content so the system is inherently explosion safe. Proper redox control may be affected with $\mathrm{CO} / \mathrm{CO}_{2}$ ratios as low as $1 / 100$ or $1 / 1,000$ (Figure 10) although enough $C O$ must be provided to react with the specific amount of $\mathrm{Fe}_{2} \mathrm{O}_{3}, \mathrm{MnO}_{2}$, and $\mathrm{U}_{3} \mathrm{O}_{8}$. The gas phase redox control may be carried out in the spray calciner or in the collection bin exiting the calciner. Maximum temperature is limited to $800^{\circ} \mathrm{C}$ to prevent premature mineralization.

Laboratory-scale experiments are currently underway at LLNL to investigate the use of a fluidized bed redox calciner. ${ }^{7} \mathrm{Be}-$ cause of higher heat transfer rates, the unit is more compact than an equivalent spray calciner. The allowed operating temperature range is $400-800^{\circ} \mathrm{C}$. This is a larger temperature range than the spray calciner $\left(650^{\circ} \mathrm{C}-800^{\circ} \mathrm{C}\right)$ since the longer residence time of material in the fluidized bed unit allows the decomposition/reduction reactions to proceed to completion at lower temperatures.

\section{- Densification and Mineralization}

Calcined SYNROC powders ready for high temperature consolidation and mineralization need to meet the specifications listed in Table 20. In our work with simulated waste, we have found particle densities of the calcined material ranging from 3.7 to $4.0 \mathrm{~g} / \mathrm{cm}^{3}$. This slight variation in powder density has had no significant effect on the densification process or the quality of the final product. The final, fully dense waste form has a density of about $4.0 \mathrm{~g} / \mathrm{cm}^{3}$.

Analyses of $S R P$ waste show the particle size to be generally less than $70 \mu \mathrm{m}$. However, there are some particles larger than this. We believe that much larger particles can be easily accommodated during densification if the waste and SYNROC ingredients have been well mixed during spray calcination. If necessary, larger particle material that is inert and does not contain radwaste elements can also be mixed with the mainstream powder during densification.

An important powder characteristic is its packing density. This is especially important when Hot Isostatic Pressing (HIP) is employed for final consolidation. HIP experience has shown 


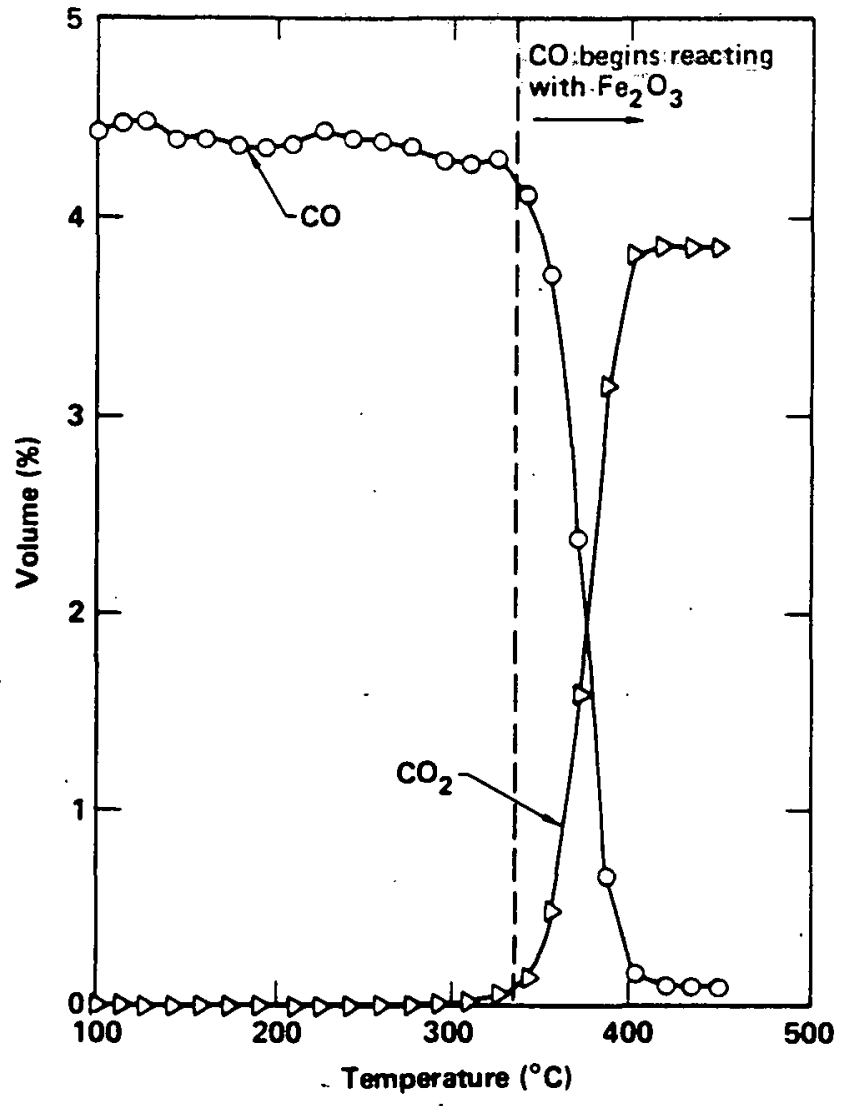

FIGURE 9. Gas Phase Redox Control may be Affected at Temperatures as low as $400^{\circ} \mathrm{C}$ with $\mathrm{CO} / \mathrm{CO}_{2}$ Ratios Below Combustion Limits

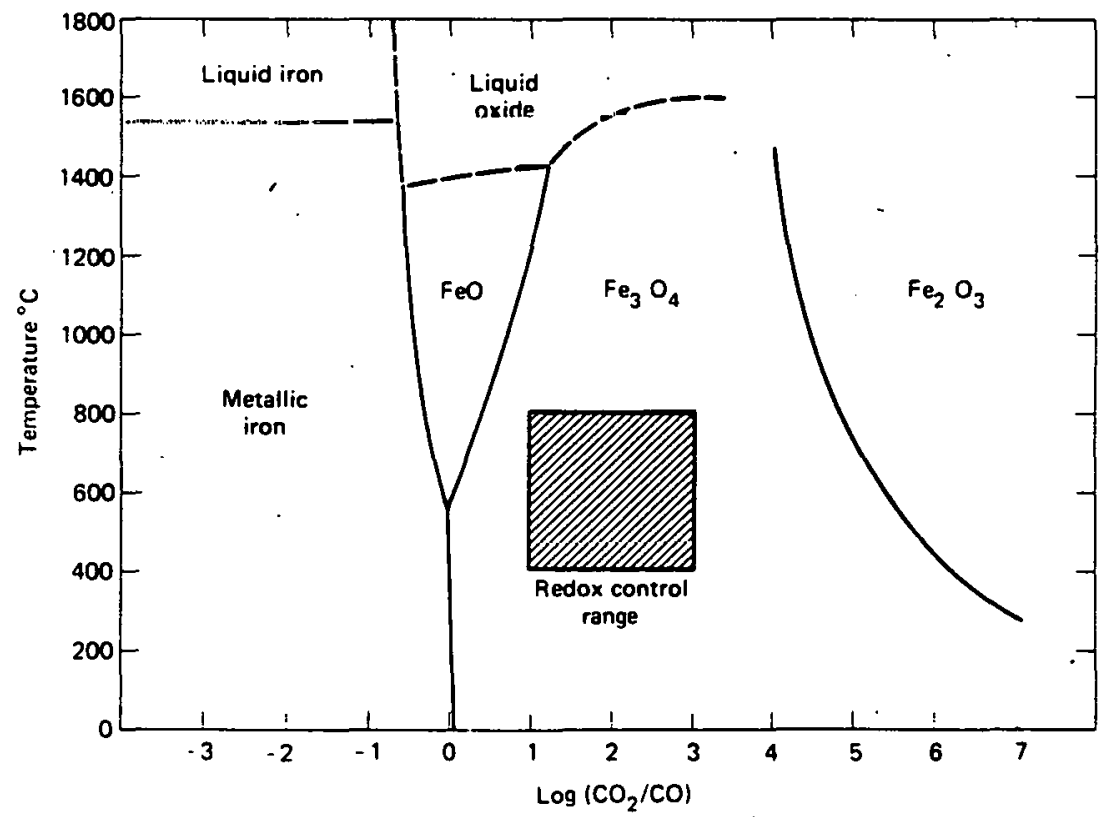

FIGURE 10. Extent of Oxidation of $\mathrm{CO}$ as it Flows Through a heated Packed Bed of $\mathrm{Pe}_{2} \mathrm{O}_{3}$. Note that above $400^{\circ} \mathrm{C}$ the Reaction Becomes very fast Rinetically 
that for powder with packing densities greater than $45 \%$ theoretical (i.e., less than $55 \%$ porosity), simple cylindrical canister designs can be used reliably. In this case the packed powder provides sufficient internal support to the metal canister to prevent buckling and distortion during densification. In the event that packing densities fall in the range of 25-35\% theoretical, a special bellows-type canister is employed which allows most of the densification to take place in the axial dimension.

\section{TABLE 20}

\section{Calcined Feed Powder Characteristics for SYNROC D Densification}

Pycnometric density;

Particle size:

Tap density:
$3.7-4.0 \mathrm{~g} / \mathrm{c}$

$\$ 70 \mu \mathrm{m}$, mean: $.15 \mu \mathrm{m}$

$1.0-1.4 \mathrm{~g} / \mathrm{cc}$

$(4.0 \mathrm{~g} / \mathrm{cc}$ is theoretica 1$)$

Laboratory experience has shown that three high temperature fabrication processes currently employed in industry have potential for the large-scale processing of SYNROC D. Two of these processes, HIP (Hot Isostatic Pressing) and HUP (Hot Uniaxial Pressing) employ pressure as well as temperature in the consolidation process. In HIP a gas is used to uniformly apply pressure to all sides of the canister during densification. Large monoliths are not practical with this process, but intermediate size cylinders (e.g., approximately 8 in. diameter) with height/diameter ratios less than 0.5 can be produced at high speed production rates. We utilize HUP in the laboratory to establish the hot pressing parameters (time, temperature, and pressure) for SYNROC $D$ powders. We have explored large scale HUP processing with the Greenleaf Corporation using simulated SYNROC $D$ powder. This company uses HUP to produce high quality ceramic cutting tool inserts of various shapes and sizes at very high throughput rates. Greenleaf Corporation has produced a few 6 in. diameter cylinders of SYNROC $C$ at simulated production rates of about a ton/day. As a result of this work, we are encouraged that relatively small high speed hot presses have the potential to process SYNROC D HLW at high throughput rates.

Finally, the third process, sintering, achieves high temperature densification under atmospheric pressure. In this case, temperature is the sole driving force to consolidate powders. 
As in HUP, large monoliths are difficult to produce. Additionally, binders and lubricants must be added so that the powder can be prepressed into free-standing parts before sintering in a furnace. We have demonstrated in the laboratory on small parts that SYNROC $D$ can be processed by sintering. However, on the basis of our preliminary studies, we do not believe that sintering will be cost competitive with either HIP or HUP for remote large scale processing of HLW SYNROC D powder.

A typical SYNROC D powder can be hot pressed over a large range of temperatures and pressures. The region of acceptability is defined by those conditions which will produce a high density waste form with only a small amount of residual closed porosity (bulk density greater than $92 \%$ of theoretical). The time at temperature and pressure is more significant to the HUP process because high throughput rates for medium size monoliths require short time periods at maximum temperatures. The data show that densification can be achieved in 5-10 minutes, at 4000 psi pressure. Time is less important in HIP where the time to reach thermal equilibrium in large monoliths is greater than the time required to densify smaller samples.

In the case of HIP, there is considerable flexibility in the required temperature and pressure. This is an important factor in the consideration of SYNROC D processing. We have calculated for a full size canister the required time to thermally equilibrate large waste powder compacts. In our calculations we have assumed a packing density of $35 \%$ and a bellows canister size 26 in. diameter by 58 in. high. Our laboratory studies have shown that packing densities at $35 \%$ can be achieved by controlling the solids/liquid ratio of the slurry feed during spray calcination.

\section{- Effects of HIP Canister Size on Cycle Time and Throughput}

The capacity of other canister sizes as a function of packing density are given in Figure 11. HIP shrinkage studies for bellows canisters have shown that we can expect this 26 in. canister to finish at approximately 22 in. diameter by 31 in. height. Each canister would contain approximately 0.4 metric ton of SRP waste. At a waste loading of $60 \%$ the total SYNROC D waste is approximately 0.7 metric ton per canister. As shown in Figure 12, for a $35 \%$ T.D. powder packing, two 26 in. canisters per day would have to be processed to meet a one metric ton/day waste throughput objective.

For a $35 \%$ theoretical packing density it will take less than 24 hours to preheat the HIP canister to a center line temperature of $800^{\circ} \mathrm{C}$ before charging the canister to the HIP furnace. 


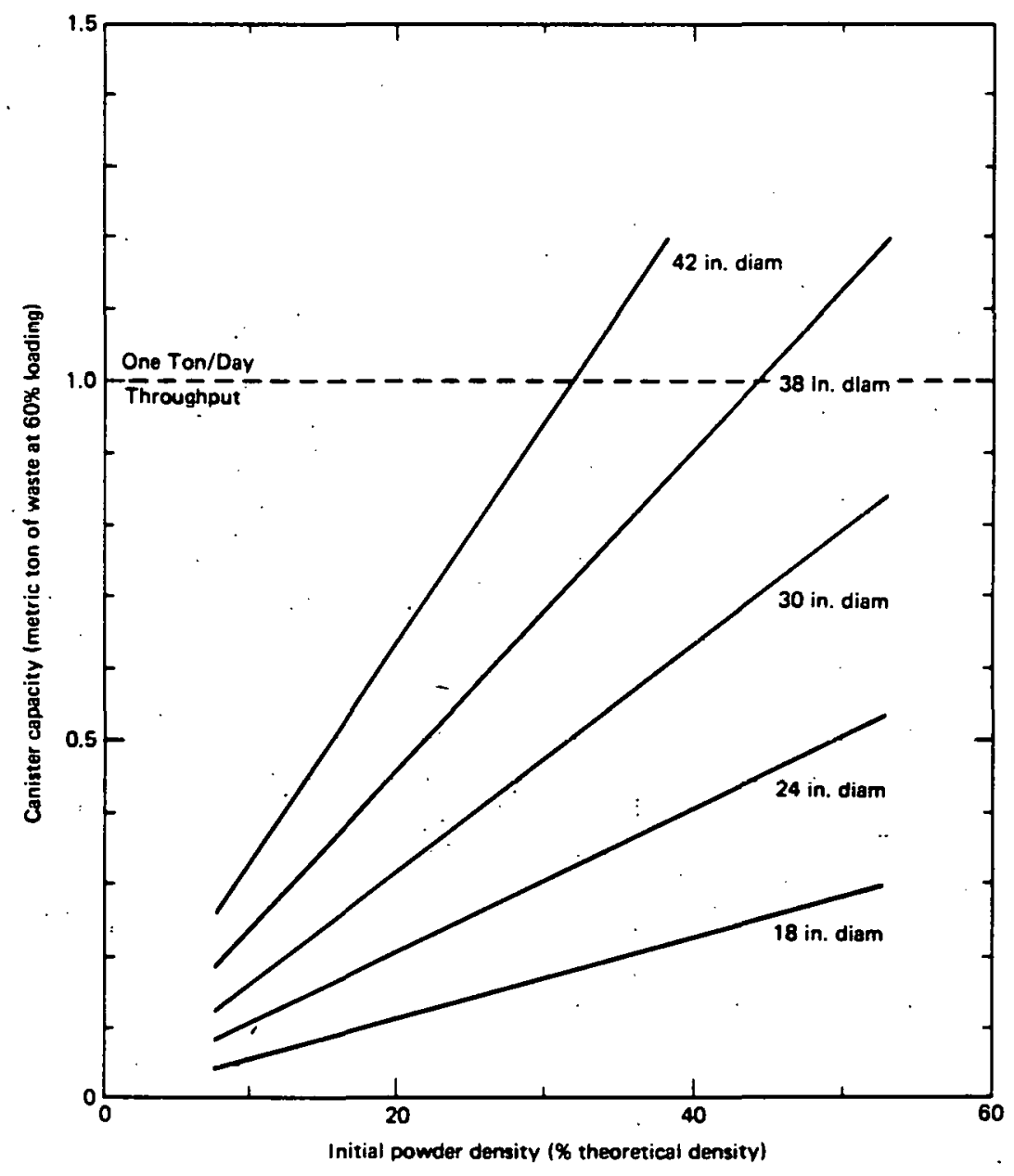

PIGORE 11. HIP Canister Capacity in Metric Tons. Initial Canister Height is $58^{\circ}$. Waste Loading is $60 \%$. Theoretical Density is $4.0 \mathrm{~g} / \mathrm{cc}$. 


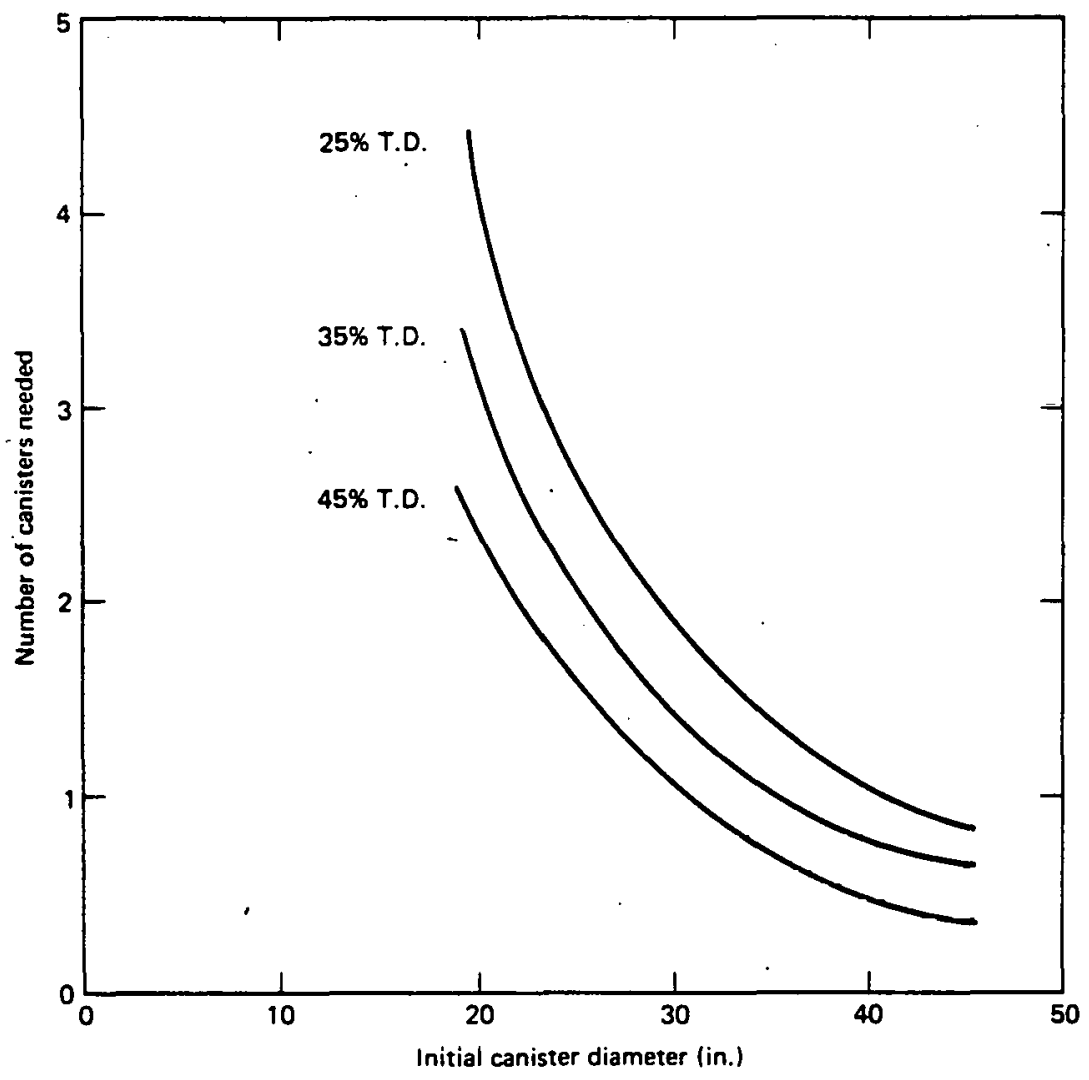

FIGURE 12. Number of HIP Canisters Required to Process One Metric Ton of SRP Waste Per Day. Initial Canister Height is 58". Diametrical Shrinkage is 17\%. Waste Loading is 607. Theoretical Density is $4.0 \mathrm{~g} / \mathrm{cc}$. 
Large industrial HIP furnaces are always loaded hot in a continuous process. Once the preheated canister is loaded into the HIP unit; it will take about 11 hours to process the canister and cool the HIP to $800^{\circ} \mathrm{C}$ for recharging. This includes a three hour hold period at maximum temperature. After cooling the HIP unit to $800^{\circ} \mathrm{C}$, the canister would be transfered to a controlled cooling furnace. The total HIP cycle time is expected to be approximately 11 hours. Industrial experience has shown that large HIP systems can be operated on a 12-hour cycle under similar time - temperature profiles. Therefore, a single HIP unit can be projected to process two canisters/day at a SRP waste rate of one metric ton/day throughput.

Because of the controlled cool down and the fact that this waste form is predominantly crystalline, the extent of cracking in SYNROC monoliths is expected to be much less severe than that encountered in the borosilicate glass process.

Radioactive Demonstration of Westinghouse Gel-Glass Process PNL. The radioactive demonstration of the Westinghouse gel glass process was completed. High-level waste was denitrated, mixed with gel-forming chemicals and sintered. Problems were experienced during the denitration phase of the demonstration because the waste would become self-boiling after it was denitrated and would boil itself dry. This problem was remedied by adding a small volume of water to the denitrated feed. The test was then completed. Leach tests will now be conducted to evaluate the product.

A major problem in radioactive tests had always been a transfer of the high-level liquid waste from the storage tanks to the test equipment in an efficient, simple manner. A new system was designed, fabricated, and installed which has solved this problem. Waste can now be obtained in a short period of time, and the unused material can be easily returned to the storage tanks.

Large-Scale Glass Melter Development Program - SRL. In support of DWPF, the TNX facility of SRL is operating a Waste Vitrification Pilot Plant. This pilot plant consisting of a feed system, joule-heated glass melter, and off-gas treatment system is operating with synthetic waste as feed materials. Prior to September 1981 , the glass melter was at operating temperature $1150^{\circ} \mathrm{C}$ - for fourteen months. During this period a total of 75 tons of glass was produced. In the latter stages of the experimental program, the melter was modified for slurry feeding which was defined as the new DWPF reference process. With slurry feeding a glass melt flux rate of 11 pounds per hour per square foot was easily attained. (The reference rate is eight pounds per hour per square foot.) 
After shutdown in September, the melter was disassembled and inspected. Initial inspections revealed no corrosion or erosion problems. The Incone $1^{\circledR}$ components - electrodes, thermowell, argon bubbler, and riser heater - which are in contact with molten glass, exhibited a maximum, average corrosion rate of 0.5 mils per day. This rate is in close agreement with earlier data obtained from smaller, laboratory melters. The melter refractory material, Monofrax ${ }^{(8)} 3$ by Carborundum, exhibited a total, maximum corrosion of $\sim 1.0$ inch. This is approximately $1 / 2$ of the anticipated rate. Experience -with this melter has indicated that both Incone ${ }^{\oplus}$ and $\mathrm{K}-3$ refractory are satisfactory materials for the DWPF process.

One -problem noted during the inspection of the melter, was an accumulation of $\sim 7$ inches of hard spinel on the melter floor. Spinel is a bi-metallic oxide which has a higher melting point than the base glass. The spinel formed because of low temperatures in the bottom of the melter. Spinel can be easily eliminated in future melters by raising the temperature in the floor of the melter. This can be accomplished by adding additional power to the bottom of the melter or by reducing the heat lost through the melter floor.

Another large-scale melter, designated the "Large-Slurry-Fed -Melter (LSFM)," is presently being installed and should start up in January 1982. This melter will demonstrate (1) a new glass containment philosophy (multi-layer refractories instead of watercooled walls), (2) the elimination of spinel formations, and (3) a two year "melter life.

Ful1-Scale Slurry-Fed In-Can Melter - SRL. Two types of melters have been developed for immobilization of SRP high-level radioactive waste. The reference melter for the Defense Waste Processing Facility (DWPF) is a slurry-fed continuous joule-heated melter. The backup melter design is a slurry-Fed In-Can Melter ( SICM).

In the SICM process, a stainless steel canister is placed in a large tube furnace and heated to $1050^{\circ} \mathrm{C}$. Waste and glass formers are fed as an aqueous slurry, which dries and melts. Feed is added continuously until the canister is full. The furnace is maintained at $1050^{\circ} \mathrm{C}$ for six hours, then the canister is cooled and removed to complete the cycle. Off-gas is cooled by injection of a cooling medium and treated to remove contaminants.

SRL has tested large-scale melters of both designs. Five runs have been made on a full-scale SICM process, but more development work would be needed for a complete canyon design. However, no further experiments are planned at this time. Future glass melter development at SRL will focus exclusively on the reference continuous melter process. 
follows :

The key results and conclusions of the SRL SICM study are as

- A rate of 0.9 tons/day was demonstrated for the fill part of the SICM cycle with a 2-ft-dia. can. This is equivalent to an average rate at $100 \%$ attainment of 0.5 to 0.7 tons/day depending on the time required for the non-fill part of the cycle.

- Low temperature steam injected near the off-gas line entrance works well as an off-gas cooling medium. About 1.5 to 2.0 pounds of steam are required for each pound of uncooled offgas. If the off-gas is cooled, mechanical cleaning of the offgas line is required infrequently, if at all. Cooling of the off-gas prevents glass frit accumulation which can plug the line.

- More development work is required to ensure that the melter feed nozzle remains open. In these tests, a rod is used periodically to clear plugs of dried feed which formed on the outside of the nozzle.

- Instrumentation required for the canister would be a continuous glass level monitor. An argon bubbler was found accurate and reliable for this purpose.

Inconel 690 Wear Tests in the Small Cylindrical. Melter - SRL. The Small Cylindrical Melter (SCM) has now been in operation at TNX for two years. During this period experimental data have been gathered concerning the corrosion of Inconel 690 in defense waste glasses. The wear rate of Inconel 690 in glass in a defense waste melter can vary from 0.1 to $6 \mathrm{mils} /$ day $(.04-2.2$ inches/yr) depending upon direct current (DC), temperature, melter operating mode (idling or feeding), local glass velocity, and possibly other factors. Some of these factors are identified and, where possible, quantified from SCM data. Possible effects of slurry formate feed remain to be determined.

The following mechanisms which may affect the wear rate of Inconel 690 in DWPF melters are listed in order of decreasing importance:

- Uncontrolled direct current (DC) in the melt pool may result in a wear rate of up to $6.0 \mathrm{mils} / \mathrm{day}$. Less than $100 \mathrm{ma}$ seems to have little effect.

- The wear rate may range from $0.38-1.8 \mathrm{mils} /$ day when feeding the melter at a nominal bulk temperature of $1150^{\circ} \mathrm{C}$. The wear rate appears to drop sharply below $1000^{\circ} \mathrm{C}$. 
- Changing the melter operating mode from idling to feeding $168 \mathrm{hrs} /$ week results in a sharp increase in wear rate $(2.5-8 X)$.

- Changing the melter operating mode from feeding $40 \mathrm{hrs} /$ week to 168 hours/week has little effect on the wear rate.

- The effect of changing the powdered feed composition from $211 /$ TDS to $131 /$ TDS has little effect on the wear rate.

- The wear rate is not significantly affected by the presence of 0.4 wt $\% \mathrm{Na}_{2} \mathrm{SO}_{4}$ in the melter feed.

- The wear rate is not significantly affected by the presence of 0.3 wt \% anthracite coal or graphite in the melter feed.

- The effect of glass velocity on the wear rate is uncertain.

- The effect of prolonged slurry feeding on the wear rate is not yet known.

FINAL HANDLING $(1.4)$

Canister Development and Characterization (1.4.1).

High-Level Waste Canister Development - PNL. The basic experimental work on barrier canister materials was completed this quarter. The metal samples, that have been in a brine autoclave for.six months, will be cleaned, weighed, and examined. A wall section from a full-scale titanium canister will also be characterized. These results, a long with those from FY 1981, will be reported along with a conceptual barrier canister design in a topical report this year. The purpose of this study is to demonstrate the basic feasibility of using a primary storage canister as an engineered barrier for disposal.

The basic data have been developed to establish a reference commercial ceramic waste form. The ceramic form is SYNROC, which was selected as the reference form because of the results from the defense waste alternative studies. Detailed data on SYNROC containing commercial waste are very limited. However, a tentative definition has been developed. The SYNROC form will contain 15 wt \% waste (5-year-old, Barnwell flowsheet) and will be hotpressed into a heavy-walled canister with a nominal inside diameter of $35 \mathrm{~cm}$ and a length of $3 \mathrm{~m}$. This canister will be similar to the canister for glass that is described elsewhere. ${ }^{8}$ Additional details on the reference definition will be developed and summarized in an informa 1 report. 
Helium Verification for DWPF Canister Leak Tests - SRL. It is necessary to verify that the DWPF canister is leak tight prior to off-plant shipment from the Interim Storage Facility at some indefinite time in the future. Current plans are to provide the means to perform a leak test by inserting a rupturable helium container inside the nozzle of the DWPF canister at the time the weld closure is made. When desired, the helium in the container will be released inside the DWPF canister by triggering a fusible plug or rupture disk. A standard helium leak test then would be performed. The need exists at the time the leak test is to be made to:

- Verify that the helium is still contained prior to rupturing

- Verify that the helium has been released after rupturing

The presence or absence of helium in the rupturable container prior to the DWPF canister leak test can be verified by a simple thermal neutron transmission measurement provided $1 / 2$ gram of ${ }^{3} \mathrm{He}$ gas is included in the helium container. The large thermal neutron absorption cross section $\left(\sigma_{a}=5327 b\right)$ of ${ }^{3} \mathrm{He}$ provides the basis for the measurement.

Calculated counting rates are summarized below:

Open beam (no interposed absorber) $=100,000 \mathrm{c} / \mathrm{m}$

DWPF canister with intact He container $=60 \mathrm{c} / \mathrm{m}$

DWPF canister with He container ruptured and gas contained $=3900 \mathrm{c} / \mathrm{m}$

DWPF canister with helium escaped $=3,500 \mathrm{c} / \mathrm{m}$

The factor of $\sim 50$ change in counting rate that occurs when the He is released provides the required assurance that a valid helium leak test will be made.

An experimental mockup to confirm the feasibility of the method will be performed. 


\section{REFERENCES}

1. G. D. Campbel1, Heat Transfer Analysis for In Situ Disposal of Nuclear Wastes in Single and Double-Shell Underground Storage Tanks, RHO-LD-171, Rockwell Hanford Operations, Richland, WA (October 1981).

2. Conceptual Design Report, Mobile Volume Reduction System for Rockwell International Hanford Operations. ATI-069-001, Rockwell Hanford Operations, Richland, WA (October 1981).

3. Composite Quarterly Technical Report. Long-Term High-Level Waste Technology. DP-81-157-3. Savannah River Laboratory, Aiken, SC, July - September .1981 (January 1982).

4. M. D. Merz, D. Atteridge, and G. Dudder. Materials Characterization Center: Meeting on Impact Testing of Waste Forms Summary Report. PNL-4007, Pacific Northwest Laboratories, Richland, WA (October 1981).

5. R. D. Peters and S. C. Slate. Fracturing of Simulated HighLevel Waste Glass in Canisters. PNL-3948. Pacific Northwest Laboratories, Richland, WA (September 1981).

6. R. B. Rozsa and C. L. Hoenig. SYNROC Processing Options. UCRL-53187, Lawrence Livermore National Laboratory, Livermore, CA (1981).

7. R. E. Schindler et al: Development of a Fluidized-Bed Calciner and Post-Treatment Processes for Solidification of Commercial Fuel-Reprocessing Liquid Waste. ICP-1136. Idaho National Engineering Laboratory, Idaho Falls, ID (1977).

8. S. C. Slate, W. A. Ross, and W. L. Partain. Reference Commercial High-Level Waste Glass and Canister Definition. PNL-3838. Pacific Northwest Laboratories, Richland, WA (1981). 
DP- $81-157-4$

\section{DISTRIBUTION}

Copy

1 J. M. Gaver, DOF,-SR

2 R. P. Denise

3 T. B. Hindman

4 J. Tseng

5-7 W. B. Wilson

8-9 J. J. Schreiber, DOE/RL

10-11 S. A. Mann, DOE-CH

$12-13$ S. W. Ahrends, $\mathrm{DOE}-\mathrm{OR}$

$14-15$ R. Y. Lowrey, DOE-AL

16-17 J. P. Hamrick, DOE-ID

18 J. B. Whitsett

19-20 S. G. Harbinson, DOE-SAN

21 S. Meyers, DOE-HQ

22 W. Carbiener, DOE-ONWI

23 G. K. Oerte1, DOE-GERMANTOWN

24 G. H. Daly

25 C. A. Heath

26 R. D. Walton

27 D. J. McGoff/R. Wooley

28 J. E. Dieckhoner/S.P. Cowan

29-31 J. L. Deichman, RHO

32 K. A. Gasper

33 J. R. Wetch

34-36 T. R. Row, ORNL

37 Carlos Bamberger

38 J. E. Mendel, PNL

39-40 T. D. Chikalla

41 S. C. Slate

42 L. J. Jardine, ANL

43 J. H. Kittel

44 J. A. Kyger

45 M. J. Steindler

46-48 J. R. Berreth, ICPP

49-51 J. H. Campbel1, LLNL

52-53 A. B. Martin, RES

54 R. E. De Wames

55 C. A. Knox (MS)

56 R. P. Turcotte

57 W. J. Bjorklund

58 D. E. Harrison, WEST

59 J. H. Saling

60 J. M. Pope

61 J. O'Keefe, NASA

62 S. Alterescu

63 H. J. Magnani

64 L. L. Hench

65 R. Roy

66 H. Palmour

67 P. W. Levy

68 R. Cook

69 N. S. Mc Intyre

70 C. J. Northrup

71 P. B. Macedo

72 S. Chizzik

73 R. Charles

74 R. Ewing

75 F. Ver Snyder

76 D. W. Ready

77 A. R. Cooper

78 S. Wiederhorn

79 J. H. Hutchins

80 J. I. Stevens

81 M. W. Davis

82 A. Schneider

83-12y TIS File, SRL

130-443 DOE-TIC (for distribution under TID-4500 Category UC-70, Nuclear Waste Management) 